\title{
Key Challenges to Digital Financial Services in Emerging Economies: The Indian Context
}

\author{
Nripendra P. Rana* \\ School of Management \\ Swansea University \\ Fabian Way, Swansea, SA1 8EN, UK \\ Email:nrananp@gmail.com \\ Sunil Luthra \\ Department of Mechanical Engineering \\ State Institute of Engineering and Technology \\ Nilokheri, Haryana, India \\ Email: sunilluthra1977@gmail.com \\ H. Raghav Rao \\ Department of ISCS, COB \\ University of Texas at San Antonio \\ Texas, USA \\ Email:hr.rao@utsa.edu
}

\begin{abstract}
Purpose: Digital Financial Services (DFS) have substantial prospect to offer a number of reasonable, appropriate and secure banking services to the underprivileged in developing countries through pioneering technologies such as mobile phone based solutions, digital platforms and electronic money models. DFS allow unbanked people to obtain access to financial services through digital technologies. However, DFS face tough challenges of adoption. Realising this, the aim of this paper is to identify such challenges and develop a framework.

Design/Methodology/Approach: We develop a framework of challenges by utilising Interpretive Structural Modelling (ISM) and Fuzzy MICMAC approach. We explored eighteen such unique set of challenges culled from the literature and further gathered data from two sets of expert professionals. In the first phase, we gathered data from twenty-nine professionals followed by eighteen professionals in the second phase. All were pursuing Executive MBA programme from a metropolitan city in South India. The implementation of ISM and fuzzy MICMAC provided a precise set of driving, linkage and dependent variables that were used to derive a framework.
\end{abstract}

Findings: ISM model is split in eight different levels. The bottom level consists of a key driving challenge V11 (i.e. high cost and low return related problem) whereas the topmost level consists of two highly dependent challenges namely V1 (i.e. risk of using digital services) and V14 (i.e. lack of trust). The prescribed ISM model shows the involvement of 'high cost and low return related problem (V11)', which triggers further challenges of DFS.

Originality/value: None of the existing research has explored key challenges to DFS in detail nor formulated a framework for such challenges. To the best of our knowledge, this is the first paper on DFS that attempts to collate its challenges and incorporate them in a hierarchical model using ISM and further divide them into four categories of factors using fuzzy MICMAC analysis.

Keywords: Digital Financial Services, Challenges, ISM, Fuzzy MICMAC, Emerging Economies, India

Paper Type Research Paper 


\section{Introduction}

Digital financial services (DFS) are the significant financial resolutions for cultivating financial inclusion (Buckley and Malady, 2015). DFS provides services to the underprivileged using advanced skills, digital platforms and electronic money models (Scott et al., 2017; David-West et al., 2018). Digital channels can allow cost to be considerably low for both customers and service providers through use by isolated and underserved residents (Baker et al., 2007; Alam and Imran, 2015; Lloyds et al., 2016; Tarhini et al., 2016; AFI Global, 2017; Thorseng and Grisot, 2017). Adoption and use of digital technologies allows millions of people to move out of the poverty every year (Gates Foundation, 2017). However, a vast majority of the world population fall into poverty due to various issues such as health, finance and other astonishments. A number of those people living in or near the poverty line lack even the most elementary banking services.

The statistics specifies that only $16 \%$ of the population living on daily wages of lower than $\$ 2$ have formal bank accounts. The situation for women and those who live in rural areas is even worse. According to Global Financial Inclusion database of World Bank, 2.5 billion people across the world do not have their accounts in any financial institution. This makes it difficult for them to make any financial transactions using electronic media. For this reason, the most disadvantaged households operate almost entirely with cash even today. As a result, such population entirely depends on cash, assets and informal money-lenders to meet their everyday financial requirements (Gates Foundation, 2017).

\subsection{Research Motivations}

Per the annual Measuring the Information Society Report (2017), subscription to the mobilecellular networks extends to the majority of the population of the world, and $95 \%$ of the world's population reside in areas covered through mobile phone signals. While $47 \%$ of the world's population had online internet access by 2016 , the remaining part of the population are still deprived of connectivity. The motivation behind introducing DFS is to mitigate the ongoing problem of under-banked and unbanked population of the society to ensure that they actively participate with the financial sectors in the developing and emerging market economies (DavidWest et al., 2018).

The mobile phone has become the most favoured mode not only for communication but also for digital financial activities. However, there is still a lack of payment through mobile wallets in the developing world (Buckley and Mas, 2016; Tarhini et al., 2016; Ashraf et al., 2017; Patil et al., 2017; Asongu and Nwachukwu, 2018; Sharma et al., 2018). For example, in India, 60\% of its 1.2 billion population are under-banked despite the fact that $75 \%$ of the overall population 
possess mobile phones. Like other emerging economies, around 67\% Indians trust in cash transactions. The statistics also indicate that only $10 \%$ of the country's population make use of debit/credit cards while the rest rely on informal channels like Hawalas (transferring money without money movement) (Amarante Consulting Group, 2014). Low penetration of DFS in the country gives rise to some basic questions, which we have attempted to answer through this research as follows:

RQ1: What are current key challenges that inhibit growth of DFS in emerging economies, specifically India?

RQ2: Are these key challenges interrelated? If yes, what kind of relationships exists?

RQ3: Can these challenges be classified into major groups for their ease of removal?

RQ4: Does there exist any framework of key challenges that can be used to improve and enhance DFS and make it more sustainable?

Manyika et al. (2016) found that Indians lose more than \$2 billion every year in inevitable income simply because it takes time for money to travel from a bank to the other locations. In such scenarios, the innovative technologies of DFS offer an avenue for saving potential time and gaining efficiency of financial services delivery at low expense, particularly to the underprivileged section of society. In 2020, mobile phones are estimated to serve around 250 million people. However, there are still a number of challenges, which need to be overcome (Amarante Consulting Group, 2014; Srivastava and Sharma, 2017). This research study will classify and analyse numerous critical challenges pertaining to DFS and develop a framework using them.

Considering the above discussion, the following objectives are set for this study: [i] Recognise the key challenges that inhibit DFS growth in India; [ii] Assess the interrelationships between key challenges identified through literature review and cluster challenges into various categories and their similarity among them. [iii] Build a framework of identified challenges to efficiently utilize DFS in the country.

Interpretive Structural Modelling (ISM) and fuzzy MICMAC are considered as suitable approaches to: [i] discover links between the designated challenges; [ii] classify them as per their interrelation linkages, [iii] build a structural model (Sindhu et al., 2016). The developed structural model could guide practitioners, governmental bodies and policymakers in removing key challenges to DFS in emerging economies. The extension of fuzzy MICMAC over the traditional MICMAC approach with ISM would allow managers not only to excerpt any unseen links between challenges, but also highlight the strengths of relationships between them (Luthra and Mangla, 2018). 
The remaining sections of the paper are structured as follows - the next section highlights the prior literature on DFS and identifies research gaps. Further, Section 3 explains the methodology used in this paper. Subsequently, findings of this work are provided in Section 4 i.e. Data Analysis and Results. Section 5 discusses findings with managerial/practical implications. Finally, the paper concludes with future research directions in Section 6.

\section{Prior Research}

This section contains the literature on DFS, current account of DFS in Indian context and identification of major challenges of DFS in the country. Research gaps are also used to highlight a theoretical lens that underpins the study.

\subsection{Digital Financial Services}

Financial services for the underprivileged have experienced a transformation over the last decade. The developments in technology have resulted in the evolution of new business models and the potential to make DFS at the heart of financial transformation in future (Mattern and McKay, 2018). DFS constitutes of a wide variety of advanced technologies such as mobile phone enabled solutions and structured electronic payment platforms (David-West et al., 2018). In other words, DFS are a vast range of services that are retrieved and delivered using digital channels such as credits, payments, savings, insurance etc. These range of services are enabled by devices such as electronic cards, chips, tablets, phablets, biometric devices and any other electronic system (AFI Global, 2016). DFS offer more flexibility for its customers in retrieving financial services. In less-developed nations, DFS can increase the percentage of the people taking part in the financial services systems, specifically among customers from rural areas who have not experienced access of financial/banking services in the past (Finau et al., 2016). The literature shows that customers in less developed and developing countries often prevent or discourage use of DFS (including mobile phone based solutions, digital payment platforms and electronic money models). For example, Lauer and Lyman (2015) considered risks of using digital services through mobile based banking, electronic money or digital payment platforms by the digitally excluded or underserved population as one of the challenges for DFS. Fatima (2011) found safety and reliability issues, privacy issues and week or poor authentication process as other three challenges of DFS. Harsh and Wright (2016) discuss other challenges including lack of awareness, limited knowledge about the benefits of DFS, lack of digital literacy and issues related to technology and networking. Similarly, other issues include lack of training and skills to agents and mobile network operators (MNOs), legal and regulatory issues (Chauhan, 2015), lack of keeping pace with new technologies (Holley, 2015), high cost 
and low return related issue (Microsave, 2016), universal unavailability of Internet (Wright et al., 2013), failure to reach out to the large majority of consumers, lack of greater integration and interoperability, lack of trust, problem of dormancy, inability to transact in low value and gender disparities in mobile ownership (Briggs, 2016).

\subsection{Current Status of DFS in India}

Whereas around $8-10 \%$ of the households in the UK, $10-15 \%$ in the USA and $7-10 \%$ in France do not have their bank accounts, the situation in developing nations is far more critical where a sizable number (i.e. 25-65\%) of households are disadvantaged because of not having basic accounts in banks (Sundaram and Sriram, 2016). In India, Prime Minister Narendra Modi launched the digitization system on the July $1^{\text {st }}, 2015$. The key purpose of this program was to ensure the online connectivity for people living in rural areas by supporting them with highspeed network connectivity. The government has also been developing an efficient structure of unified payment to offer speedy and secure transfer of services to relevant recipients (Rani, 2016). The Intermedia Financial Inclusion Insight (FII) survey of 45,000 Indian adults conducted in 2014 indicated that only $0.3 \%$ of adults in India use mobile money (Kumar, 2015). Hence, there is an enormous scope of using innovative technologies for DFS (Ahluwalia and Bhatti, 2017). Currently, DFS are not prevalent in India because of a range of key challenges such as inadequate infrastructure, lack of trust, lack of knowledge and additional cost involved etc. (Dwivedi et al., 2016). Key challenges of DFS in emerging economies have been discussed in the next section.

\subsection{Key Challenges of DFS in Emerging Economies}

For identifying the key challenges, we explored the literature through keywords such as inhibitors, barriers and hurdles that suppress growth of DFS in developing countries. We used databases such as Science Direct, Scopus and search engines like Google and Google Scholar to search for published journals, conference proceedings, reports and books. We found a total of 106 papers out of which 49 were found to meet our criteria for this research. With help of comprehensive literature review, 18 key challenges of DFS were chosen (see Table 1). These challenges were further authenticated through inputs received from experts (see Section 4).

Table 1. Major DFS challenges

\begin{tabular}{|l|l|l|l|}
\hline V\# & Challenge & Brief description & References \\
\hline V1 & Risk of using digital services & $\begin{array}{l}\text { Security and privacy risks for digital } \\
\text { services like mobile banking can stop } \\
\text { individuals from using DFS }\end{array}$ & $\begin{array}{l}\text { Leeflang et al. (2014); Lauer } \\
\text { and Lyman (2015); Gupta et } \\
\text { al. (2017); Scott et al. } \\
\text { (2017); David-West et al. } \\
\text { (2018) }\end{array}$ \\
\hline V2 & Safety and reliability issues & $\begin{array}{l}\text { Consumer engagement of using DFS } \\
\text { will reduce with security gaps and } \\
\text { nonexistence of defence against }\end{array}$ & $\begin{array}{l}\text { Fatima (2011); Kumar and } \\
\text { Goyal (2016); Tarhini et al. } \\
\text { (2016); Gupta (2017); Rana } \\
\text { et al. (2018) }\end{array}$ \\
\hline
\end{tabular}




\begin{tabular}{|c|c|c|c|}
\hline & & $\begin{array}{l}\text { fraudulence and cyberattacks in the } \\
\text { DFS }\end{array}$ & \\
\hline V3 & Privacy issues & $\begin{array}{l}\text { Consumer trust and engagement for } \\
\text { using DFS will reduce with an } \\
\text { intervention of private and } \\
\text { confidential information }\end{array}$ & $\begin{array}{l}\text { Fatima (2011); Weill and } \\
\text { Woerner (2015); Castle et al. } \\
\text { (2016); Athey et al. (2017); } \\
\text { Rana et al. (2018) }\end{array}$ \\
\hline V4 & $\begin{array}{l}\text { Weak or poor authentication } \\
\text { process }\end{array}$ & $\begin{array}{l}\text { Consumer intention to use DFS will } \\
\text { reduce with weak or poor } \\
\text { authentication process of digital } \\
\text { services }\end{array}$ & $\begin{array}{l}\text { Fatima (2011); Karlan et al. } \\
\text { (2016); David-West et al. } \\
\text { (2018) }\end{array}$ \\
\hline V5 & Lack of digital literacy & $\begin{array}{l}\text { Consumer can be discouraged from } \\
\text { using DFS with lack of digital literacy }\end{array}$ & $\begin{array}{l}\text { Dwivedi et al. (2016); Harsh } \\
\text { and Wright (2016); Khokhar } \\
\text { (2016); Gabor and Brooks } \\
\text { (2017); Nedungadi et al. } \\
\text { (2018); Rana et al. (2018) }\end{array}$ \\
\hline V6 & $\begin{array}{l}\text { Less information about } \\
\text { advantages of DFS }\end{array}$ & $\begin{array}{l}\text { Consumer intention of using DFS but } \\
\text { they do have proper information } \\
\text { about advantages of DFS }\end{array}$ & $\begin{array}{l}\text { Harsh and Wright (2016); } \\
\text { Lloyd et al. (2016); } \\
\text { Siddiquee (2016); Gupta et } \\
\text { al. (2017); Nedungadi et al. } \\
\text { (2018); Rana et al. (2018) }\end{array}$ \\
\hline V7 & $\begin{array}{l}\text { Technology and networking } \\
\text { issues }\end{array}$ & $\begin{array}{l}\text { Consumers/Mobile Network } \\
\text { Operators (MNOs) trust toward DFS } \\
\text { will lower by facing the critical issues } \\
\text { such as digital disruptions }\end{array}$ & $\begin{array}{l}\text { Au and Kauffman (2008); } \\
\text { Harsh and Wright (2016); } \\
\text { Scott et al. (2017); Rana et } \\
\text { al. (2018) }\end{array}$ \\
\hline V8 & $\begin{array}{l}\text { Lack of training to } \\
\text { agents/Mobile } \\
\text { Operators (MNOs) }\end{array}$ & $\begin{array}{l}\text { Lack of designing the right type of } \\
\text { agent training and skills development } \\
\text { program to keep agents updated with } \\
\text { information required to serve the } \\
\text { consumers can reduce agents' } \\
\text { intention to effectively run the digital } \\
\text { financial services program }\end{array}$ & $\begin{array}{l}\text { Chauhan (2015); Kanobe et } \\
\text { al. (2017); Nesse et al. } \\
\text { (2018) }\end{array}$ \\
\hline V9 & Legal and regulatory issues & $\begin{array}{l}\text { Lack of legal and regulatory } \\
\text { framework or guidelines for digital } \\
\text { services increases risks and } \\
\text { discourages consumer to effectively } \\
\text { use digital financial services }\end{array}$ & $\begin{array}{l}\text { Weber and Darbellay } \\
\text { (2010); Kemp (2013); } \\
\text { Chauhan (2015); Scott et al. } \\
\text { (2017); David-West et al. } \\
\text { (2018) }\end{array}$ \\
\hline V10 & $\begin{array}{l}\text { Lack of adaptably of new } \\
\text { technologies }\end{array}$ & $\begin{array}{l}\text { Banking systems are negatively } \\
\text { influenced toward fostering DFS with } \\
\text { the Lack of adaptably of new } \\
\text { technologies. }\end{array}$ & $\begin{array}{l}\text { Fitzgerald et al. (2014); } \\
\text { Holley (2015); Scott et al. } \\
\text { (2017); Das et al. (2018); } \\
\text { Rana et al. (2018) }\end{array}$ \\
\hline V11 & $\begin{array}{l}\text { High cost and low return } \\
\text { related problem }\end{array}$ & $\begin{array}{l}\text { High costs attached with small returns } \\
\text { have led digital services an } \\
\text { unattractive proposition for } \\
\text { commercial banks and profit-making } \\
\text { entities toward successfully rolling } \\
\text { out the digital financial services }\end{array}$ & $\begin{array}{l}\text { Leeflang et al. (2014); } \\
\text { Microsave (2016) }\end{array}$ \\
\hline V12 & $\begin{array}{l}\text { Universal unavailability of } \\
\text { Internet }\end{array}$ & $\begin{array}{l}\text { Lack of physical network to provide } \\
\text { online services to every part of the } \\
\text { country could be a substantial } \\
\text { challenge, which can adversely } \\
\text { influence the significant use of DFS }\end{array}$ & $\begin{array}{l}\text { Wright et al. (2013); Rana et } \\
\text { al. (2018) }\end{array}$ \\
\hline V13 & $\begin{array}{l}\text { Unreachability } \\
\text { consumers }\end{array}$ & $\begin{array}{l}\text { Consumer can be deprived of using } \\
\text { DFS if they have a lack of any type of } \\
\text { online payment arrangement } \\
\text { including mobile money to reach } \\
\text { from nowhere to the critical mass }\end{array}$ & $\begin{array}{l}\text { Chauhan (2015); Lauer and } \\
\text { Lyman (2015); West (2015); } \\
\text { Deichmann et al. (2016); } \\
\text { Foster (2016); Rana et al. } \\
\text { (2018) }\end{array}$ \\
\hline V14 & Lack of trust & $\begin{array}{l}\text { Lack of trust can stop consumer from } \\
\text { availing the benefits of DFS }\end{array}$ & $\begin{array}{l}\text { Lifen Zhao et al. (2010); } \\
\text { Leeflang et al. (2014); } \\
\text { Shareef et al. (2018) }\end{array}$ \\
\hline V15 & $\begin{array}{l}\text { Lack of wider integration and } \\
\text { interoperability }\end{array}$ & $\begin{array}{l}\text { Lack of assimilation and } \\
\text { interoperability of non-branch } \\
\text { banking for both urban and rural }\end{array}$ & $\begin{array}{lll}\text { Wright et al. } & \text { (2013); } \\
\text { Bourreau and } & \text { Valletti }\end{array}$ \\
\hline
\end{tabular}




\begin{tabular}{|l|l|l|l|}
\hline & & $\begin{array}{l}\text { consumers can reduce the pace of } \\
\text { DFS offered to consumers }\end{array}$ & $\begin{array}{l}\text { (2015); David-West et al. } \\
(2018)\end{array}$ \\
\hline V16 & Problem of dormancy & $\begin{array}{l}\text { The issue related to non-use of mobile } \\
\text { and other digital services by the } \\
\text { registered active mobile/digital } \\
\text { service users could reduce the } \\
\text { effective angelow et al. } \\
\text { implementation of DFS }\end{array}$ & $\begin{array}{l}\text { Aazer and Rowan (2016); } \\
\text { Chandrasekhar and Ghosh } \\
(2018)\end{array}$ \\
\hline V17 & $\begin{array}{l}\text { Inability to transact in low } \\
\text { value }\end{array}$ & $\begin{array}{l}\text { Incompetence to hold enormous } \\
\text { capacity of small value exchanges at } \\
\text { low cost can reduce the effectiveness } \\
\text { of using digital financial services }\end{array}$ & $\begin{array}{l}\text { Kendall et al (2011); } \\
\text { Buckley (2015); Karlan et } \\
\text { al. (2016); Gomber et al. } \\
(2018)\end{array}$ \\
\hline V18 & $\begin{array}{l}\text { Gender disparities in mobile } \\
\text { ownership }\end{array}$ & $\begin{array}{l}\text { Reduced access for women of the } \\
\text { mobile smart phones decreases their } \\
\text { utilization of DFS }\end{array}$ & $\begin{array}{l}\text { Asongu (2015); Santosham } \\
\text { (2015); Adam et al. (2018); } \\
\text { Sinha (2018) }\end{array}$ \\
\hline
\end{tabular}

\subsection{Research Gaps}

As a critical indicator of economic health in India, DFS permit users to protect against predictable and unforeseen events, allowing industrialists and traders to capitalise on fresh and creative dealings and to handle their supply chains, and make it possible for people, industries, financial-services providers and governments to control transactions proficiently (Scott et al., 2017; David-West et al., 2018). However, same amount of access of financial services is not enjoyed by individuals and businesses in emerging economies in comparison to their equivalents in developed economies. As many as $45 \%$ or two billion individuals in the emerging economies' adult population do not have their bank accounts or any kind of mobile money services. In addition, half of all such businesses in developing economies lack adequate access to the services they need to prosper (Dara, 2018).

DFS studies and reports are primarily centred on African countries such as Kenya where mobile technology is pervasive (Haider, 2018). However, very little focus has been given to other countries (e.g. Setia et al., 2013; Buckley and Malady, 2015; Aaluri et al., 2016; Finau et al., 2016). These studies have broadly brushed through DFS in general and there has not been any comprehensive research on DFS that has been undertaken in the context of India (Srivastava and Sharma, 2017). The current paper addresses that gap by assessing and analysing different critical challenges that constrain the growth of DFS in India.

\section{Research Methodology}

Interpretive Structural Modelling (ISM) is a systematic and collaborative approach for scrutinising interlinks between factors (Warfield, 1974). It helps researchers to build structural a model among factors based on experts' inputs (Luthra et al., 2014). The main disadvantage of the ISM approach is that it reflects only inter-relationships between factors. It assumes an identical relevance and is represented through binary codes (i.e. 0 or 1). However, links between variables may not always be same strength and hence considering this is a value 
addition to this methodology (Khan and Haleem, 2015). In this paper, to improve the sensitivity of conventional MICMAC, fuzzy set theory is used.

For creating interrelationship among factors, we note that a number of methods are available in the literature such as DEMATEL, ANP etc. However as compared to these methods, the integrated ISM-fuzzy MICMAC analysis based model (Gorane and Kant, 2013) is designed to provide a better understanding of the links and dependencies between recognised variables as it discovers hidden connections and allows the addition of intermediate values for determining the power of interrelationships between them.

In this work, ISM and fuzzy MICMAC approach are implemented using various steps (Agi and Nishant, 2017) as follows:

[1] Identify the factors associated with the issue in hand. For example, in this research, the critical challenges for DFS are explored through extant literature, relevant blogs from websites, and grey literature, [2] Develop circumstantial associations between challenges of DFS emerging from literature. We collected data to analyse and understand these relationships, [3] Develop structural self-interaction matrix (SSIM) of identified challenges through pairwise interaction between challenges. We used specialist responses, which were then integrated to develop the overall scenario for pairwise interactions. This eventually resulted in SSIM, [4] Develop initial reachability matrix (IRM) through SSIM. IRM is then converted into final reachability matrix (FRM). We establish the concept of transitivity between variables to develop FRM, [5] Calculate driving and dependence power for each variable listed after assigning transitivity to the FRM. We add up all ones (including transitive and non-transitive) row-wise and column-wise to reach to the final values, [6] Reachability set consists of variables it influences. However, antecedent set constitutes of the variable itself and other variables that influence this variable. Intersection set is then computed as a set of common elements from both reachability and antecedent sets. Develop various partition levels based on identifying the same content of reachability and intersection sets, [7] Develop digraph for challenges listed in FRM, which is presented through elements positioned at various levels that is obtained using reachability and intersection sets, [8] Use fuzzy MICMAC to build a graph of all challenges. That would be drawn by calculating driving and dependence power for challenges, and [9] Analyse the consistency of the ISM model using specialist estimations. Some appropriate actions and recommendations are derived if there is a consistency in their estimations.

\section{Data Analysis}

Data related to interrelationships between DFS related challenges were gathered from 29 respondents who had experience working in different companies specifically in financial 
domains and were pursuing their EMBA programme from a leading academic institution in Bangalore - a Southern multicultural software city also known as Silicon Valley of India. We used convenience sampling approach to select these individuals as one of the co-authors was teaching this cohort of respondents. The respondents belonged to various software companies and held different positions including delivery manager, IT manager, technical architect etc. Table 2 presents respondents' demographic traits as shown below.

Table 2. Respondent details

\begin{tabular}{|c|c|c|}
\hline Demographic Characteristic & \# of Respondents & $\%$ \\
\hline \multicolumn{3}{|l|}{ Highest qualification } \\
\hline Undergraduate & 21 & 72.41 \\
\hline Postgraduate & 08 & 27.59 \\
\hline \multicolumn{3}{|l|}{ Work experience (in years) } \\
\hline$<5$ & 01 & 03.45 \\
\hline $5-10$ & 12 & 41.38 \\
\hline $11-15$ & 10 & 34.48 \\
\hline $16-20$ & 05 & 17.24 \\
\hline$>20$ & 01 & 03.45 \\
\hline \multicolumn{3}{|c|}{ Company size (in terms of number of employees) } \\
\hline $51-250$ & 02 & 06.90 \\
\hline$>250$ & 27 & 93.10 \\
\hline \multicolumn{3}{|l|}{ Sector Classification } \\
\hline Private & 16 & 55.17 \\
\hline Public & Nil & Nil \\
\hline MNCs & 12 & 41.38 \\
\hline Regulatory Bodies & 01 & 03.45 \\
\hline \multicolumn{3}{|c|}{ Company's annual turnover (In million dollars) } \\
\hline$<=100$ & Nil & Nil \\
\hline $101-500$ & 01 & 03.45 \\
\hline $501-1,000$ & Nil & Nil \\
\hline $1,001-5,000$ & Nil & Nil \\
\hline $5,001-10,000$ & 01 & 03.45 \\
\hline$>10,000$ & 27 & 93.10 \\
\hline
\end{tabular}

The first part of the survey questionnaire contains the demographic details of respondents. The second part constitutes the list of challenges that required respondents' views on each challenge on the scale of ' 1 ' indicating 'not significant' to ' 5 ' representing 'extremely significant'. We recorded their responses and took a mean of all of them to understand the relevance of these challenges in context of DFS in India.

We retained only entries with mean score of 3 or above in order to capture the important aspects. In addition, we also asked experts to add any further challenges that they thought appropriate and missing in the list, or comment on any existing challenges. Given that the mean values for all identified challenges were found to be greater than 3 , all identified challenges of DFS were selected for further analysis. ISM is a sound method for developing a collective understanding for the relationships between various challenges of DFS found through the literature review (Janssen et al., 2018). The used methodology is shown in Figure 1.

[Figure 1 about here] 


\subsection{Self-Structured Interaction Matrix (SSIM)}

We develop SSIM (see Table 3) filled out with contextual relationships between each pair of challenges by compiling various matrices responded by each expert. SSIM is presented in Table 3 using symbols $\mathrm{V}, \mathrm{A}, \mathrm{X}$ and $\mathrm{O}$ collated from specialist feedback, which have the following interpretation:

[1] V: Variable i helps achieve or has influence on Variable j; [2] A: Variable j helps achieve or has influence on Variable i; [3] X: Variables $\mathrm{i}$ and $\mathrm{j}$ help achieve or influence each other; and [4] O: Variables i and j are not related to each other (Hughes et al., 2016; Kumar et al., 2016; Rana et al., 2019). 


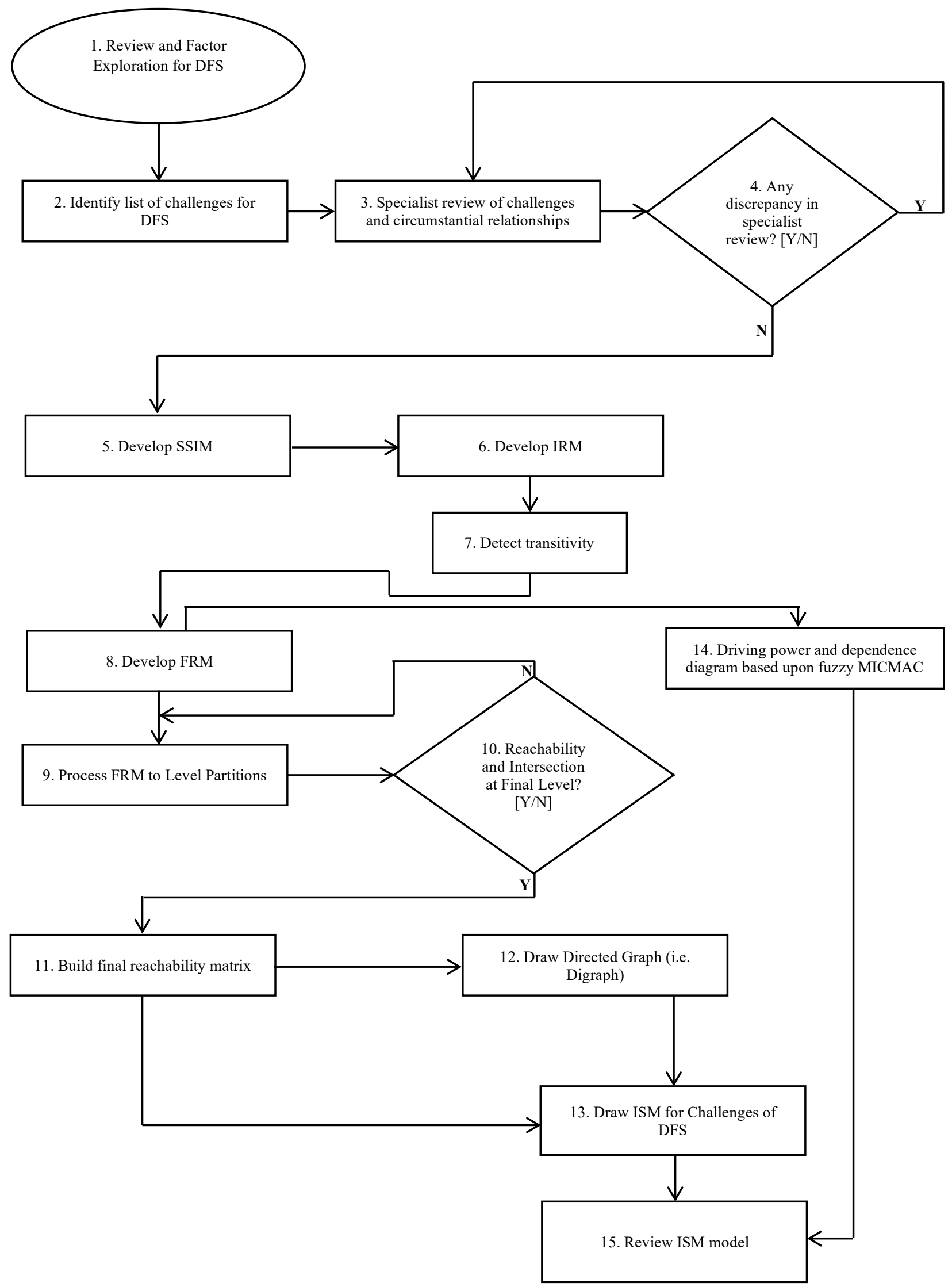

Figure 1. ISM-Fuzzy MICMAC flow chart (Source: Hughes et al., 2016; Janssen et al., 2018) 
Table 3. Self-Structured Interaction Matrix for challenges of DFS

\begin{tabular}{|l|c|c|c|c|c|c|c|c|c|c|c|c|c|c|c|c|c|}
\hline V[i/j] & V18 & V17 & V16 & V15 & V14 & V13 & V12 & V11 & V10 & V9 & V8 & V7 & V6 & V5 & V4 & V3 & V2 \\
\hline V1 & A & A & A & A & X & A & A & O & A & A & A & A & A & A & A & A & A \\
\hline V2 & A & A & A & A & V & A & A & O & A & X & A & A & A & A & A & X & - \\
\hline V3 & A & A & A & A & V & A & A & O & A & X & A & A & A & A & A & - & - \\
\hline V4 & A & A & A & X & V & A & A & A & A & V & A & A & A & A & - & - & - \\
\hline V5 & V & V & V & V & V & V & X & A & V & V & V & V & V & - & - & - & - \\
\hline V6 & A & O & X & V & V & X & A & A & A & O & V & V & - & - & - & - & - \\
\hline V7 & A & X & A & V & V & A & A & A & A & V & X & - & - & - & - & - & - \\
\hline V8 & A & X & A & V & V & A & A & A & A & V & - & - & - & - & - & - & - \\
\hline V9 & O & A & O & A & V & A & O & A & O & - & - & - & - & - & - & - & - \\
\hline V10 & X & V & O & V & V & V & A & A & - & - & - & - & - & - & - & - & - \\
\hline V11 & V & V & V & V & V & V & V & - & - & - & - & - & - & - & - & - & - \\
\hline V12 & O & V & V & V & V & V & - & - & - & - & - & - & - & - & - & - & - \\
\hline V13 & A & V & X & V & V & - & - & - & - & - & - & - & - & - & - & - & - \\
\hline V14 & A & A & A & A & - & - & - & - & - & - & - & - & - & - & - & - & - \\
\hline V15 & A & A & A & - & - & - & - & - & - & - & - & - & - & - & - & - & - \\
\hline V16 & A & V & - & - & - & - & - & - & - & - & - & - & - & - & - & - & - \\
\hline V17 & A & - & - & - & - & - & - & - & - & - & - & - & - & - & - & - & - \\
\hline V18 & - & - & - & - & - & - & - & - & - & - & - & - & - & - & - & - & - \\
\hline
\end{tabular}

\subsection{Development of IRM and FRM}

As per the procedural step of ISM, SSIM is further converted into IRM. Binary numbers (i.e. 0 and 1) were used for developing IRM by replacing different symbols including V, A, X, and $\mathrm{O}$ in SSIM. Converting these symbols into binary numbers is done as per the following procedure (Al-Muftah et al., 2017; Dwivedi et al., 2017; Mangla et al., 2017; Mishra et al., 2017):

[1] For symbol ' $V$ ' in SSIM use ' 1 ' in ( $i, j)$ entry and ' 0 ' in $(j, i)$ entry, [2] For symbol ' $A$ ' in SSIM use ' 0 ' in ( $i, j)$ entry and ' 1 ' in $(j, i)$ entry, [3] For symbol ' $X$ ' in SSIM use ' 1 ' in both (i, j) and (j, i) entries, and finally, [4] For symbol ' $O$ ' in SSIM use ' 0 ' in both (i, j) as well as $(j, i)$ entries.

By substituting these symbols with the corresponding binary numbers into the specified entries, IRM (see Table 4) is developed for DFS related challenges. Further, IRM is converted into FRM by employing the rule of transitivity as presented in procedural steps for ISM.

Table 4. IRM for challenges related to DFS

\begin{tabular}{|c|c|c|c|c|c|c|c|c|c|c|c|c|c|c|c|c|c|c|}
\hline $\mathrm{C \#}$ & V1 & $\mathrm{V} 2$ & V3 & $\mathrm{V} 4$ & V5 & V6 & V7 & V8 & V9 & V10 & V11 & V12 & V13 & V14 & V15 & V16 & V17 & V18 \\
\hline V1 & 1 & 0 & 0 & 0 & 0 & 0 & 0 & 0 & 0 & 0 & 0 & 0 & 0 & 1 & 0 & 0 & 0 & 0 \\
\hline V2 & 1 & 1 & 1 & 0 & 0 & $\mathrm{O}$ & 0 & 0 & 1 & 0 & $\mathrm{O}$ & $\mathrm{O}$ & 0 & 1 & $\mathrm{O}$ & 0 & 0 & 0 \\
\hline V3 & 1 & 1 & 1 & 0 & 0 & 0 & $\mathrm{O}$ & 0 & 1 & $\mathrm{O}$ & 0 & $\mathrm{O}$ & $\mathrm{O}$ & 1 & $\mathrm{O}$ & $\mathrm{O}$ & 0 & 0 \\
\hline V4 & 1 & 1 & 1 & 1 & 0 & $\mathrm{O}$ & 0 & 0 & 1 & $\mathrm{O}$ & 0 & $\mathrm{O}$ & 0 & 1 & 1 & $\mathrm{O}$ & 0 & 0 \\
\hline V5 & 1 & 1 & 1 & 1 & 1 & 1 & 1 & 1 & 1 & 1 & 0 & 1 & 1 & 1 & 1 & 1 & 1 & 1 \\
\hline V6 & 1 & 1 & 1 & 1 & 0 & 1 & 1 & 1 & 0 & 0 & 0 & 0 & 1 & 1 & 1 & 1 & 0 & 0 \\
\hline V7 & 1 & 1 & 1 & 1 & 0 & 0 & 1 & 1 & 1 & 0 & 0 & 0 & 0 & 1 & 1 & 0 & 1 & 0 \\
\hline v8 & 1 & 1 & 1 & 1 & 0 & 0 & 1 & 1 & 1 & 0 & 0 & 0 & 0 & 1 & 1 & 0 & 1 & 0 \\
\hline V9 & 1 & 1 & 1 & 0 & 0 & 0 & 0 & 0 & 1 & 0 & 0 & 0 & 0 & 1 & 0 & 0 & 0 & 0 \\
\hline V10 & 1 & 1 & 1 & 1 & 0 & 1 & 1 & 1 & 0 & 1 & $\mathrm{O}$ & $\mathrm{O}$ & 1 & 1 & 1 & $\mathrm{O}$ & 1 & 1 \\
\hline V11 & 0 & 0 & 0 & 1 & 1 & 1 & 1 & 1 & 1 & 1 & 1 & 1 & 1 & 1 & 1 & 1 & 1 & 1 \\
\hline V12 & 1 & 1 & 1 & 1 & 1 & 1 & 1 & 1 & 0 & 1 & 0 & 1 & 1 & 1 & 1 & 1 & 1 & 0 \\
\hline V13 & 1 & 1 & 1 & 1 & 0 & 1 & 1 & 1 & 1 & $\mathrm{O}$ & 0 & 0 & 1 & 1 & 1 & 1 & 1 & 0 \\
\hline V14 & 1 & 0 & 0 & 0 & 0 & 0 & 0 & 0 & 0 & 0 & 0 & 0 & 0 & 1 & 0 & 0 & 0 & 0 \\
\hline V15 & 1 & 1 & 1 & 1 & 0 & 0 & 0 & 0 & 1 & 0 & 0 & 0 & 0 & 1 & 1 & 0 & 0 & 0 \\
\hline V16 & 1 & 1 & 1 & 1 & 0 & 1 & 1 & 1 & 0 & 0 & 0 & 0 & 1 & 1 & 1 & 1 & 1 & 0 \\
\hline V17 & 1 & 1 & 1 & 1 & 0 & 0 & 1 & 1 & 1 & 0 & 0 & 0 & 0 & 1 & 1 & 0 & 1 & 0 \\
\hline V18 & 1 & 1 & 1 & 1 & 0 & 1 & 1 & 1 & 0 & 1 & 0 & 0 & 1 & 1 & 1 & 1 & 1 & 1 \\
\hline
\end{tabular}


FRM (see Table 5) is thus obtained by considering the transitive relations between challenges from IRM.

Table 5. FRM for the Challenges of Digital Financial Services

\begin{tabular}{|l|l|l|l|l|l|l|l|l|l|l|l|l|l|l|l|l|l|l|l|}
\hline V\# & V1 & V2 & V3 & V4 & V5 & V6 & V7 & V8 & V9 & V10 & V11 & V12 & V13 & V14 & V15 & V16 & V17 & V18 & DRP \\
\hline V1 & 1 & 0 & 0 & 0 & 0 & 0 & 0 & 0 & 0 & 0 & 0 & 0 & 0 & 1 & 0 & 0 & 0 & 0 & 02 \\
\hline V2 & 1 & 1 & 1 & 0 & 0 & 0 & 0 & 0 & 1 & 0 & 0 & 0 & 0 & 1 & 0 & 0 & 0 & 0 & 05 \\
\hline V3 & 1 & 1 & 1 & 0 & 0 & 0 & 0 & 0 & 1 & 0 & 0 & 0 & 0 & 1 & 0 & 0 & 0 & 0 & 05 \\
\hline V4 & 1 & 1 & 1 & 1 & 0 & 0 & 0 & 0 & 1 & 0 & 0 & 0 & 0 & 1 & 1 & 0 & 0 & 0 & 07 \\
\hline V5 & 1 & 1 & 1 & 1 & 1 & 1 & 1 & 1 & 1 & 1 & 0 & 1 & 1 & 1 & 1 & 1 & 1 & 1 & 17 \\
\hline V6 & 1 & 1 & 1 & 1 & 0 & 1 & 1 & 1 & $1^{*}$ & 0 & 0 & 0 & 1 & 1 & 1 & 1 & $1^{*}$ & 0 & 13 \\
\hline V7 & 1 & 1 & 1 & 1 & 0 & 0 & 1 & 1 & 1 & 0 & 0 & 0 & 0 & 1 & 1 & 0 & 1 & 0 & 10 \\
\hline V8 & 1 & 1 & 1 & 1 & 0 & 0 & 1 & 1 & 1 & 0 & 0 & 0 & 0 & 1 & 1 & 0 & 1 & 0 & 10 \\
\hline V9 & 1 & 1 & 1 & 0 & 0 & 0 & 0 & 0 & 1 & 0 & 0 & 0 & 0 & 1 & 0 & 0 & 0 & 0 & 05 \\
\hline V10 & 1 & 1 & 1 & 1 & 0 & 1 & 1 & 1 & $1^{*}$ & 1 & 0 & 0 & 1 & 1 & 1 & $1 *$ & 1 & 1 & 15 \\
\hline V11 & $1^{*}$ & $1^{*}$ & $1^{*}$ & 1 & 1 & 1 & 1 & 1 & 1 & 1 & 1 & 1 & 1 & 1 & 1 & 1 & 1 & 1 & 18 \\
\hline V12 & 1 & 1 & 1 & 1 & 1 & 1 & 1 & 1 & $1^{*}$ & 1 & 0 & 1 & 1 & 1 & 1 & 1 & 1 & $1^{*}$ & 17 \\
\hline V13 & 1 & 1 & 1 & 1 & 0 & 1 & 1 & 1 & 1 & 0 & 0 & 0 & 1 & 1 & 1 & 1 & 1 & 0 & 13 \\
\hline V14 & 1 & 0 & 0 & 0 & 0 & 0 & 0 & 0 & 0 & 0 & 0 & 0 & 0 & 1 & 0 & 0 & 0 & 0 & 02 \\
\hline V15 & 1 & 1 & 1 & 1 & 0 & 0 & 0 & 0 & 1 & 0 & 0 & 0 & 0 & 1 & 1 & 0 & 0 & 0 & 07 \\
\hline V16 & 1 & 1 & 1 & 1 & 0 & 1 & 1 & 1 & $1^{*}$ & 0 & 0 & 0 & 1 & 1 & 1 & 1 & 1 & 0 & 13 \\
\hline V17 & 1 & 1 & 1 & 1 & 0 & 0 & 1 & 1 & 1 & 0 & 0 & 0 & 0 & 1 & 1 & 0 & 1 & 0 & 10 \\
\hline V18 & 1 & 1 & 1 & 1 & 0 & 1 & 1 & 1 & $1^{*}$ & 1 & 0 & 0 & 1 & 1 & 1 & 1 & 1 & 1 & 15 \\
\hline DNP & 18 & 16 & 16 & 13 & 03 & 08 & 11 & 11 & 16 & 05 & 01 & 03 & 08 & 18 & 13 & 08 & 11 & 05 & 184 \\
\hline
\end{tabular}

[Note: *: Adding transitivity, C\#: Challenge ID; DNP: Dependence Power, DRP: Driving Power]

Further, the driving and dependence power for each driver were calculated by adding the entries of ' 1 ' across both rows and columns from FRM (see Table 5).

\subsection{Partitioning of Levels}

We separated challenges into different levels in development of hierarchical structure of DFS using both IRM and FRM. Different sets such as reachability set, antecedent set and intersection set are formed to divide these challenges into different levels.

For example, reachability set is constituted of a variable itself and the other variables affected by it. Antecedent set constitutes of a variable itself and other variables that affect this. Intersection set is a juncture of reachability and antecedent sets. We have marked challenge(s) as Level I where both reachability and intersection sets become equal. For instance, challenges such as 'risk of using capital services (V1)' and 'lack of trust (V14)' have been assigned to Level I because in both these instances the intersection of reachability set and antecedent set result in reachability set. Table 6 puts both V1 and V14 as Level I as they fulfil the specified condition.

Table 6. First iteration the challenges of digital financial services

\begin{tabular}{|l|l|l|l|l|}
\hline V\# & Reachability Set $\left(\mathbf{R}_{\mathbf{i}}\right)$ & Antecedent Set $\left(\mathbf{A}_{\mathbf{i}}\right)$ & $\mathbf{R}_{\mathbf{i}} \cap \mathbf{A}_{\mathbf{i}}$ & $\mathbf{L}$ \\
\hline V1 & 1,14 & $1,2,3,4,5,6,7,8,9,10,11,12,13,14,15,16,17,18$ & 1,14 & I \\
\hline V2 & $1,2,3,9,14$ & $2,3,4,5,6,7,8,9,10,11,12,13,15,16,17,18$ & $2,3,9$ & \\
\hline V3 & $1,2,3,9,14$ & $2,3,4,5,6,7,8,9,10,11,12,13,15,16,17,18$ & $2,3,9$ & \\
\hline V4 & $1,2,3,4,9,14,15$ & $4,5,6,7,8,10,11,12,13,15,16,17,18$ & 4,15 & \\
\hline V5 & $1,2,3,4,5,6,7,8,9,10,12,13,14,15,16,17,18$ & $5,11,12$ & 5,12 & \\
\hline V6 & $1,2,3,4,6,7,8,9,13,14,15,16,17$ & $5,6,10,11,12,13,16,18$ & $6,13,16$ & \\
\hline V7 & $1,2,3,4,7,8,9,14,15,17$ & $5,6,7,8,10,11,12,13,16,17,18$ & $7,8,17$ & \\
\hline
\end{tabular}




\begin{tabular}{|l|l|l|l|l|}
\hline V8 & $1,2,3,4,7,8,9,14,15,17$ & $5,6,7,8,10,11,12,13,16,17,18$ & $7,8,17$ & \\
\hline V9 & $1,2,3,9,14$ & $2,3,4,5,6,7,8,9,10,11,12,13,15,16,17,18$ & $2,3,9$ & \\
\hline V10 & $1,2,3,4,6,7,8,9,10,13,14,15,16,17,18$ & $5,10,11,12,18$ & 10,18 & \\
\hline V11 & $1,2,3,4,5,6,7,8,9,10,11,12,13,14,15,16,17,18$ & 11 & 11 & \\
\hline V12 & $1,2,3,4,5,6,7,8,9,10,12,13,14,15,16,17,18$ & $5,11,12$ & 5,12 & \\
\hline V13 & $1,2,3,4,6,7,8,9,13,14,15,16,17$ & $5,6,10,11,12,13,16,18$ & $6,13,16$ & \\
\hline V14 & 1,14 & $1,2,3,4,5,6,7,8,9,10,11,12,13,14,15,16,17,18$ & 1,14 & I \\
\hline V15 & $1,2,3,4,9,14,15$ & $4,5,6,7,8,10,11,12,13,15,16,17,18$ & 4,15 & \\
\hline V16 & $1,2,3,4,6,7,8,9,13,14,15,16,17$ & $5,6,10,11,12,13,16,18$ & $6,13,16$ & \\
\hline
\end{tabular}

[Note: $\mathrm{C} \#=$ Challenge ID, $\mathrm{L}=$ Level, $\mathrm{V}_{\mathrm{i}}=$ Challenge[i]]

After marking a level associated with the challenge(s), we eliminated that challenge or group of challenges from the procedure. We iterate this procedure until each challenge has been labelled with at least one level. We go on until eight iterations to ensure that all challenges for DFS have obtained one or the other level for developing an ISM based model. Table 7 presents all challenges and their assigned levels.

Table 7. Levels assigned to challenges

\begin{tabular}{|c|c|c|}
\hline Iteration & Level\# & Challenges for DFS \\
\hline $1^{\text {st }}$ & I & $\begin{array}{l}\text { - } \text { Risk of using digital services (V1) } \\
\text { - } \quad \text { Lack of trust (V14) }\end{array}$ \\
\hline $2^{\text {nd }}$ & II & $\begin{array}{l}\text { - } \quad \text { Safety and reliability issues (V2) } \\
\text { - } \quad \text { Privacy issues (V3) } \\
\text { - } \quad \text { Legal and regulatory issues (V9) } \\
\end{array}$ \\
\hline $3^{\text {rd }}$ & III & $\begin{array}{l}\text { - Weak or poor authentication process (V4) } \\
\text { - Lack of greater integration and interoperability (V15) }\end{array}$ \\
\hline $4^{\text {th }}$ & IV & $\begin{array}{l}\text { - } \quad \text { Technology and networking issues (V7) } \\
\text { - } \quad \text { Lack of training and skill to agents (V8) } \\
\text { - } \quad \text { Inability to transact in low value (V17) } \\
\end{array}$ \\
\hline $5^{\text {th }}$ & V & $\begin{array}{l}\text { - Less information about advantages of DFS (V6) } \\
\text { - Unreachability of mass consumers (V13) } \\
\text { - } \quad \text { Problem of dormancy (V16) }\end{array}$ \\
\hline $6^{\text {th }}$ & VI & $\begin{array}{l}\text { - Lack of keeping pace with new technologies (V10) } \\
\text { - Gender disparities in mobile ownership (V18) }\end{array}$ \\
\hline $7^{\text {th }}$ & VII & $\begin{array}{l}\text { - Lack of digital literacy (V5) } \\
\text { - Universal unavailability of internet (V12) }\end{array}$ \\
\hline $8^{\text {th }}$ & VIII & - High cost and low return related problem (V11) \\
\hline
\end{tabular}

\subsection{Development of ISM Model}

Following the various levels for the challenges of DFS (see Table 7), we developed ISM model for challenges of DFS (see Figure 2). 


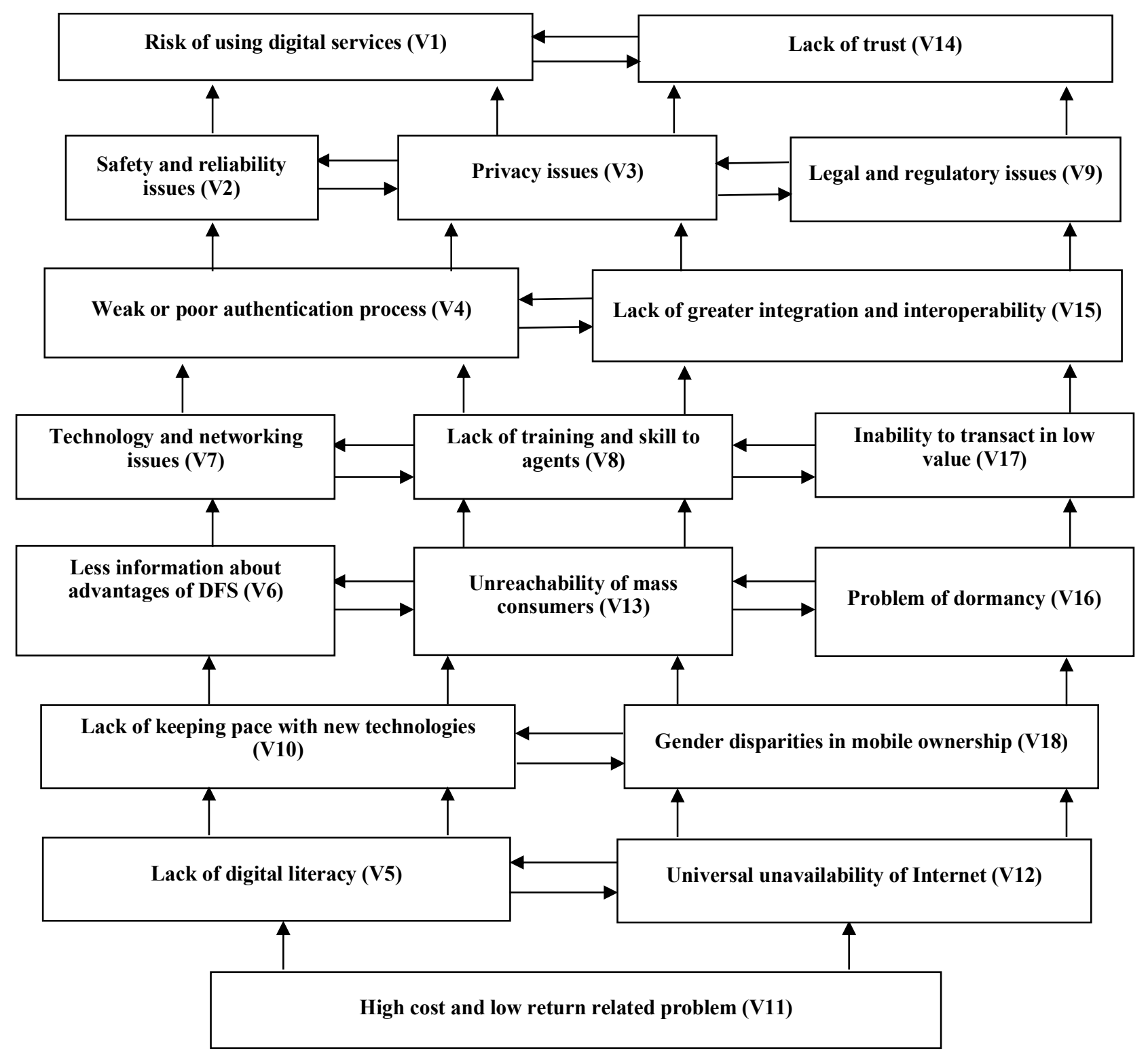

Figure 2. ISM-based model

The ISM model is split in eight different levels. The bottom level consists of a key driving challenge V11 (i.e. high cost and low return related problem) whereas the topmost level consists of two highly dependent challenges namely V1 (i.e. risk of using digital services) and V14 (i.e. lack of trust). All other challenges of DFS lie between these two extreme levels of driving and dependent challenges.

\subsection{Fuzzy MICMAC Analysis}

Although we used binary digits i.e. 0 or 1 for the formation of ISM model, this model does not allow evaluating the strength of relationships between challenges. This inability of the ISM model is overcome by considering the Fuzzy MICMAC analysis (Gorane and Kant, 2013). It has been used to analyze the challenges of DFS. The relationship between any two variables is marked as very weak, weak, strong, or very strong or they are not be related to each other. In 
fuzzy MICMAC, an additional input of probability of interaction between variables of DFS is introduced (Dubey and Ali, 2014; Sindhu et al., 2016). For this, we consider the interaction between variables on the scale of [0-1] as it is shown in Table 8 .

Table 8. Numerical values of reachability

\begin{tabular}{|l|c|c|c|c|c|c|c|}
\hline Possibility of reachability & No & Negligible & Low & Medium & High & Very High & Full \\
\hline Value & 0.0 & 0.1 & 0.3 & 0.5 & 0.7 & 0.9 & 1.0 \\
\hline
\end{tabular}

The subsequent judgment of different experts (from a cohort of 18 professionals pursuing another executive MBA programme from the same institution) was taken into account to rate the relationship between every pair of challenges. The demographic characteristics of respondents for the second round of survey are presented in Table 9.

Table 9. Expert details

\begin{tabular}{|l|l|c|c|}
\hline Category & Classification & No. of experts & \% \\
\hline \multirow{3}{*}{ Highest qualification } & Undergraduate & 15 & 83.33 \\
\cline { 2 - 4 } & Postgraduate & 03 & 16.67 \\
\hline \multirow{4}{*}{ Work experience in yeas } & $<5$ & 02 & 11.11 \\
\cline { 2 - 4 } & $5-10$ & 07 & 38.89 \\
\cline { 2 - 4 } & $11-15$ & 05 & 27.78 \\
\cline { 2 - 4 } & $16-20$ & 02 & 11.11 \\
\cline { 2 - 4 } & $>20$ years & 02 & 11.11 \\
\hline Company size & $>250$ employees & 18 & 100.00 \\
\hline \multirow{2}{*}{ Sector classification } & Private sector & 02 & 11.11 \\
\cline { 2 - 4 } & Multinational corporation & 16 & 88.89 \\
\hline \multirow{2}{*}{ Annual turnover (In million dollars) } & $501-1,000$ & 02 & 11.11 \\
\cline { 2 - 4 } & $>10,000$ & 16 & 88.89 \\
\hline
\end{tabular}

The average fuzzy direct relationship matrix (FDRM) is obtained as depicted in Table 10.

Table 10. FDRM matrix

\begin{tabular}{|c|c|c|c|c|c|c|c|c|c|c|c|c|c|c|c|c|c|c|}
\hline $\mathbf{V} \#$ & V1 & V2 & V3 & V4 & V5 & V6 & V7 & V8 & V9 & V10 & V11 & V12 & V13 & V14 & V15 & V16 & V17 & V18 \\
\hline V1 & .00 & .00 & .00 & .00 & .00 & .00 & .00 & .00 & .00 & .00 & .00 & .00 & .00 & .00 & .00 & .00 & .00 & .00 \\
\hline V2 & .55 & .00 & .59 & .00 & .00 & .00 & .00 & .00 & .39 & .00 & .00 & .00 & .00 & .59 & .00 & .00 & .00 & .00 \\
\hline V3 & .53 & .66 & .00 & .00 & .00 & .00 & .00 & .00 & .49 & .00 & .00 & .00 & .00 & .62 & .00 & .00 & .00 & .00 \\
\hline V4 & .51 & .58 & .55 & .00 & .00 & .00 & .00 & .00 & .43 & .00 & .00 & .00 & .00 & .52 & .42 & .00 & .00 & .00 \\
\hline V5 & .64 & .48 & .53 & .40 & .00 & .79 & .54 & .65 & .42 & .70 & .00 & .45 & .54 & .67 & .49 & .52 & .34 & .46 \\
\hline V6 & .50 & .46 & .44 & .54 & .00 & .00 & .33 & .39 & .00 & .00 & .00 & .00 & .60 & .52 & .44 & .58 & .00 & .00 \\
\hline V7 & .51 & .59 & .48 & .59 & .00 & .00 & .00 & .47 & .33 & .00 & .00 & .00 & .00 & .41 & .64 & .00 & .52 & .00 \\
\hline V8 & .46 & .50 & .45 & .45 & .00 & .00 & .49 & .00 & .38 & .00 & .00 & .00 & .00 & .54 & .56 & .00 & .44 & .00 \\
\hline V9 & .51 & .42 & .47 & .00 & .00 & .00 & .00 & .00 & .00 & .00 & .00 & .00 & .00 & .46 & .00 & .00 & .00 & .00 \\
\hline V10 & .54 & .46 & .59 & .60 & .00 & .46 & .63 & .52 & .00 & .00 & .00 & .00 & .54 & .61 & .59 & .00 & .31 & .24 \\
\hline V11 & .00 & .00 & .00 & .36 & .34 & .41 & .48 & .50 & .39 & .51 & .00 & .44 & .61 & .51 & .53 & .47 & .50 & .25 \\
\hline V12 & .42 & .29 & .16 & .31 & .49 & .54 & .63 & .44 & .00 & .48 & .00 & .00 & .70 & .44 & .69 & .54 & .39 & .00 \\
\hline V13 & .45 & .28 & .24 & .22 & .00 & .52 & .42 & .51 & .54 & .00 & .00 & .00 & .00 & .52 & .55 & .48 & .49 & .00 \\
\hline V14 & .62 & .00 & .00 & .00 & .00 & .00 & .00 & .00 & .00 & .00 & .00 & .00 & .00 & .00 & .00 & .00 & .00 & .00 \\
\hline V15 & .39 & .39 & .45 & .44 & .00 & .00 & .00 & .00 & .43 & .00 & .00 & .00 & .00 & .37 & .00 & .00 & .00 & .00 \\
\hline V16 & .28 & .22 & .28 & .32 & .00 & .57 & .51 & .50 & .00 & .00 & .00 & .00 & .53 & .47 & .43 & .00 & .27 & .00 \\
\hline V17 & .31 & .22 & .17 & .24 & .00 & .00 & .48 & .42 & .36 & .00 & .00 & .00 & .00 & .31 & .32 & .00 & .00 & .00 \\
\hline V18 & .17 & .24 & .21 & .23 & .00 & .28 & .21 & .21 & .00 & .21 & .00 & .00 & .47 & .32 & .28 & .31 & 0.19 & .00 \\
\hline
\end{tabular}


To obtain stabilization, the first step is to take FDRM and use the concept of fuzzy multiplication. When the sum of driving power happens to be equal to the sum of dependence power, the matrix is called a stabilised matrix (Khan and Haleem, 2012). The stabilized matrix in Fuzzy MICMAC for the challenges of DFS is obtained in the fourth stage as shown in Table 11.

[Table 11 about here]

We analysed the fuzzy stabilized matrix for the challenges of DFS to calculate driving and dependence power and the sum total of columns and rows for FRM was further computed (see Table 11). Challenges have been divided into four categories on the basis of dependence and driving power by using fuzzy MICMAC analysis. Figure 3 shows fuzzy MICMAC for the challenges of DFS.

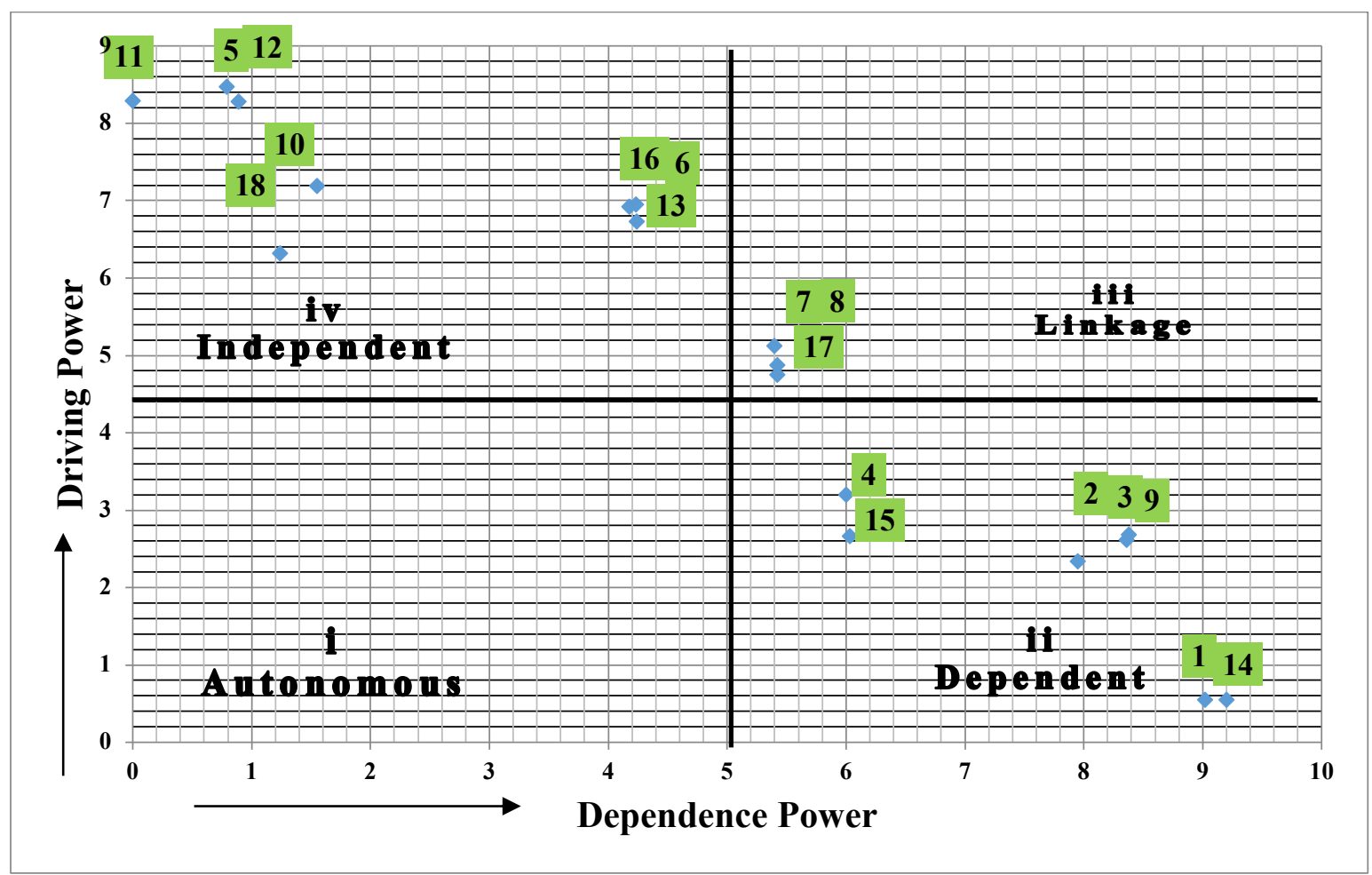

Figure 3. Fuzzy MICMAC analysis 
Table 11. Fuzzy Stabilized Matrix for challenges of DFS

\begin{tabular}{|c|c|c|c|c|c|c|c|c|c|c|c|c|c|c|c|c|c|c|c|}
\hline $\mathrm{C} \#$ & V1 & V2 & V3 & V4 & V5 & V6 & V7 & V8 & V9 & V10 & V11 & V12 & V13 & V14 & V15 & V16 & V17 & V18 & Driving Power \\
\hline V1 & .55 & .00 & .00 & .00 & .00 & .00 & .00 & .00 & .00 & .00 & .00 & .00 & .00 & .00 & .00 & .00 & .00 & .00 & 0.55 \\
\hline V2 & .59 & .59 & .42 & .00 & .00 & .00 & .00 & .00 & .49 & .00 & .00 & .00 & .00 & .59 & .00 & .00 & .00 & .00 & 2.68 \\
\hline V3 & .59 & .42 & .59 & .00 & .00 & .00 & .00 & .00 & .42 & .00 & .00 & .00 & .00 & .59 & .00 & .00 & .00 & .00 & 2.61 \\
\hline V4 & .58 & .55 & .58 & .42 & .00 & .00 & .00 & .00 & .49 & .00 & .00 & .00 & .00 & .58 & .00 & .00 & .00 & .00 & 3.20 \\
\hline V5 & .59 & .58 & .59 & .54 & .45 & .52 & .51 & .51 & .53 & .45 & .00 & .00 & .57 & .59 & .53 & .57 & .51 & .24 & 8.28 \\
\hline V6 & .54 & .54 & .54 & .52 & .00 & .57 & .51 & .51 & .54 & .00 & .00 & .00 & .53 & .54 & .55 & .52 & .51 & .00 & 6.92 \\
\hline V7 & .59 & .58 & .59 & .45 & .00 & .00 & .48 & .44 & .49 & .00 & .00 & .00 & .00 & .59 & .47 & .00 & .44 & .00 & 5.12 \\
\hline V8 & .54 & .49 & .50 & .48 & .00 & .00 & .44 & .47 & $\begin{array}{l}.49 \\
\end{array}$ & .00 & .00 & .00 & .00 & 0.5 & .48 & .00 & $\begin{array}{l}.48 \\
\end{array}$ & .00 & 4.87 \\
\hline V9 & .47 & .47 & .42 & .00 & .00 & .00 & .00 & .00 & .47 & .00 & .00 & .00 & .00 & .51 & .00 & .00 & .00 & .00 & 2.34 \\
\hline V10 & .59 & .59 & .58 & .52 & .00 & 0.52 & .51 & .51 & .52 & .21 & .00 & .00 & .52 & .59 & .52 & .52 & .49 & .00 & 7.19 \\
\hline V11 & .52 & .52 & .52 & .52 & .44 & 0.52 & .51 & .51 & .52 & .44 & .00 & .34 & .52 & .52 & .52 & .52 & .51 & .34 & 8.29 \\
\hline V12 & .59 & .59 & .58 & .54 & .00 & 0.54 & .51 & .51 & .54 & .45 & .00 & .45 & .54 & .59 & .54 & .54 & .51 & .45 & 8.47 \\
\hline V13 & .52 & .52 & .52 & .52 & .00 & 0.52 & .51 & .51 & .52 & .00 & .00 & .00 & .52 & .52 & .52 & .52 & .51 & .00 & 6.73 \\
\hline V14 & .00 & .00 & .00 & .00 & .00 & .00 & .00 & .00 & .00 & .00 & .00 & .00 & .00 & .00 & .00 & .00 & .00 & .00 & 0.55 \\
\hline V15 & .45 & .45 & .44 & .00 & .00 & .00 & .00 & .00 & .45 & .00 & .00 & .00 & .00 & .45 & .42 & .00 & .00 & .00 & 2.66 \\
\hline V16 & .54 & .54 & .54 & .54 & .00 & 0.52 & .51 & .51 & .53 & .00 & .00 & .00 & .57 & .54 & .53 & .57 & .51 & .00 & 6.95 \\
\hline V17 & .48 & .48 & .48 & .48 & .00 & 0.00 & .44 & .47 & .48 & .00 & .00 & .00 & .00 & .48 & .48 & .00 & .48 & .00 & 4.75 \\
\hline V18 & .47 & .47 & .47 & .47 & .00 & 0.47 & .47 & .47 & .47 & .00 & .00 & .00 & .47 & .47 & .47 & .47 & .47 & .21 & 6.32 \\
\hline Dependence power & 9.20 & 8.38 & 8.36 & 6.00 & 0.89 & 4.18 & 5.40 & 5.42 & 7.95 & 1.55 & 0.00 & 0.79 & 4.24 & 9.2 & 6.03 & 4.23 & 5.42 & 1.24 & 88.50 \\
\hline
\end{tabular}


We divided the challenges into four sets based on fuzzy MICMAC analysis (see Figure 3). Fuzzy MICMAC is a structural analysis that provides assessing the hierarchy of variables in quadrants as per their driving and dependence power and four quadrants are explained as:

1. Autonomous set: Challenges belonging to this set involve low driving and low dependence power (lower left quadrant). These variables have very less influence on the other variables. No variable appears in this set. It shows every designated challenge has a substantial effect on DFS.

2. Dependent set: Challenges belonging to this set include low driving but high dependence power and occupies higher rank levels in the ISM model. There are seven such challenges that come under this set. These comprise of risk of using digital services (V1), lack of trust (V14), safety and reliability issues (V2), privacy issues (V3), legal and regulatory issues (V9), weak or poor authentication process (V4) and lack of greater integration and interoperability (V15). These interdependent challenges for improving DFS.

3. Linkage set: Challenges belonging to this set involve high driving and high dependence power; and possess relatively inferior levels of prominence in the ISM model. Challenges belong to this set include technology and networking issues (V7), lack of training and skill to agents (V8) and inability to transact in low value (V17). More monitoring is required for these challenges constantly at each level to promote DFS.

4. Independent set: Challenges belonging to this set involve high driving and low dependence power; and institute the basis of ISM model. A total of eight such challenges come under this category - less information about advantages of DFS (V6), inability to reach a critical mass of consumers (V13), problem of dormancy (V16), lack of keeping pace with new technologies (V10), gender disparities in mobile ownership (V18), lack of digital literacy (V5), universal unavailability of Internet (V12) and high cost and low return related problem (V11). Practitioners and policymakers should consider such challenges in achieving anticipated aim of advancing of DFS in India. Higher driving power based challenges can certainly affect other challenges above them in the ISM model and therefore they must be taken care of on the priority basis.

\section{Discussion}

ISM model (see Figure 2) illustrates the contribution of high cost and low return related problem (V11)', which forms the basis of the other challenges for DFS. That means to overcome high cost and low return related problem, the practitioners and developers must optimise and re-engineer processes to lower costs in developing infrastructure of DFS in India. 
Further, challenges such as 'lack of digital literacy (V5)' and 'universal unavailability of internet (V12)' influence each other interdependently and act as major challenges for DFS in India. Dwivedi et al. (2016) have declared that a considerably large fraction of developing countries' population still lacks resources such as Internet and digital literacy to encourage DFS. For instance, in India, with around 6,50,000 villages, the rural population is large and relatively disconnected. Internet connectivity is a question mark in rural areas. As per a study conducted by the Internet and Mobile Association of India (IAMAI), rural India lags behind urban areas even though the Indian government has taken some steps such as investment in building critical digital infrastructure and creating national digital IDs (Aadhaar) etc. to promote DFS in these areas. Therefore, Government of India (GoI) must focus on developing Internet infrastructure and promote digital literacy among the population. Thus, the coordination of the centre Government and 29 state governments is very much required for focused efforts to increase the efficiency of DFS in India.

These challenges would lead to 'lack of keeping pace with new technologies (V10)' and 'gender disparities in mobile ownership (V18), which further lead to 'less information about advantages of DFS (V6)', 'unreachability of mass consumers (V13)' and 'problem of dormancy (V16)'. These hierarchical relationships make a lot of sense as the influence of factors such as lack of keeping pace with the modern technologies and reduced access of smartphones for the women can lead to the users' less information about advantages of DFS, its inefficacy to reach out to the critical mass and issues related to the non-use of mobile and other digital services.

Many conservative people in India believe that women are not capable of handling money transaction digitally. To promote it Indian Government launched a financial inclusion programme named 'Pradhan Mantri Jan Dhan Yojana (PMJDY)' in 2015 with a mission to provide a basic account to every adult, which was a huge success and enrolled more women than men. Some more initiatives like PMJDY are needed to encourage women to take up more employment opportunities to become financially independent. In recent years, many digital gateways have been introduced in India such as Paytm, Pay U, Pay Pal, PhonePe, CC Avenue etc. Google and Amazon have also started their digital money wallets in India. DFS have been increasing with use of online platforms but there is a need to do a lot more for making financial services more universally affordable and accessible. According to the report of IAMAI, whereas only $16 \%$ of rural users access the Internet for financial transactions, this figure goes up to $44 \%$ in urban areas. Shah and Dubhashi (2015) also highlighted the relevance of low income, unemployment and illiteracy, use of digital services by women and disabled individuals and how they are adversely affected from the mainstream of digital financial 
services. The potential reasons for this could be the lack inefficient knowledge on banking products etc. Also, lack of adequate knowledge results in confusion, apprehensions and obstacles that prevent people from availing many banking products and services. Therefore, policymakers must emphasise on framing or designing policies to make the society aware about advantages of DFS and ensure that policies reach out to a critical mass of consumers.

Challenges such as 'less information about advantages of DFS (V6)', 'unreachability of mass consumers (V13)' and 'problem of dormancy (V16)') will lead to 'technology and networking issues (V7)', 'lack of training to agents (V8)' and 'inability to transact in low value (V17)'. In particular, these challenges are associated with technology awareness, adaption and organisational issues to encourage DFS. The lack of knowledge and awareness about the benefits of DFS and non-use of mobile and other digital services may adversely affect the way agents are trained and also the inability to transact in low denominations. Moreover, the inability of online payment requirements to reach from nowhere to critical mass could influence technology and networking issues.

Technology related issues lead to 'weak or poor authentication process (V4)' and 'lack of greater integration and interoperability (V15)', which further leads to 'safety and reliability issues (V2)', 'privacy issues (V3)' and 'legal and regulatory issues (V9)'. Indian customers tend to trust older or public banks more than private or newly established banks. This lack of trust needs to be addressed by regulatory bodies through clear guidelines and effective communication. At present, over 900 million mobile users are in the country but only 40 million are mobile banking customers. Therefore, banks must think of establishing active collaboration with telecom companies for building trust, strengthening the security of mobile banking transactions including beneficiary management etc.

These challenges lead to 'risk of using digital services (V1)' and 'lack of trust (V14)'. The research of Gupta et al. (2017) and Dara (2018) also suggested that Indian banks have undertaken a number of measures to alleviate users' concerns about security. In addition, the Indian government has passed legislation covering mobile banking practices. Despite these efforts, security concerns remain a major cause for poor adoption of mobile banking in India.

\subsection{Implications for Theory}

This study provides some key implications for theory in this area of research. Collis and Hussey (2014) stated that the fundamental purpose of any academic research is to examine a research question with a view to producing knowledge. As per this statement, as there has not been any research on digital financial services in general and in the context of India in particular that has explored the key challenges of DFS yet, exploring such challenges through this research would help researchers understand the issues around the DFS. From a theoretical point of view, we 
are among the first efforts to collate relevant literature from various sources (i.e. research articles, websites/blogs on DFS etc.) to come up with a number of distinct challenges for DFS in India.

Second, none of the existing research has categorised challenges for DFS into various categories such as autonomous challenges, independent challenges, dependent challenges and linkage challenges to understand their nature. Based on the data gathered from industry experts, we have computed the driving and dependence power for each challenge in this study and assigned them to particular categories based on their power. Third, through partitioning of levels and FRM, we are also able to establish the levels of various challenges in the proposed ISM model and interlinks between challenges to understand how all of them are interconnected at various levels.

Finally, this is the first study that has developed a comprehensive framework of challenges, by collecting data from working industry experts in this domain. The ISM methodology was used to develop a framework that provides more in-depth information about the key driving and dependent challenges or some other challenges that possess both these traits and the interlinks between them. Subsequently, we collected further data from experienced respondents working in industry to understand the sensitive and more in-depth links between challenges to perform fuzzy MICMAC analysis, which helped us better analyse the position of factors in the fourquadrant MICMAC grid. By using ISM and fuzzy MICMAC approach to develop a framework of challenges of DFS and establishing further positioning of factors, this study also provides a methodological contribution to this area of research.

To summarize, we are among the first efforts to conduct a comprehensive examination of the challenges of digital financial services by defining both independent and dependent variables and other variables that possess a dual nature. Prior research on challenges of DFS does not identify and collate challenges nor does it establish causal links between them. This paper adds value to the current research on DFS by filling this gap. We consider various possible challenges from a variety of different sources and also using techniques such as ISM, MICMAC and fuzzy MICMAC to position them as dependent, independent or mediating variables to establish conceptual interlinks between them. We hope future researchers can empirically validate such links using appropriate primary data.

\subsection{Implications for Practice}

There are many positive trends towards the digital financial inclusion. The findings of this study provide some recommendation strategies in this regard. The policymakers should evaluate the widespread challenges and link them by identifying their appropriate relationships. We have evaluated different key challenges of DFS and establish contextual relationships 
between them using comprehensive literature and survey performed using specialists in this area. We also compute the driving and dependence power for each variable. The findings will allow management of banking and other financial institutions to overcome identified changes and enhance their services. The practitioners and policymakers would benefit from this research by minimising or eliminating these challenges to effectively promote DFS in India. The Government of India wants Indian economy to transact \$1 trillion of digital revenue by 2022. Therefore, joint research, learning, and collective understanding of DFS risks are needed to shape guidelines, standards, and regulations.

\section{Proposed Theoretical Model and Propositions}

Based on the developed framework, we can choose the appropriate factors to develop a potential model for DFS and create propositions for future validation. These factors also support some of the theoretical underpinning of existing research in the related field of ecommerce, m-commerce, digital payment systems and digital financial services to name a few.

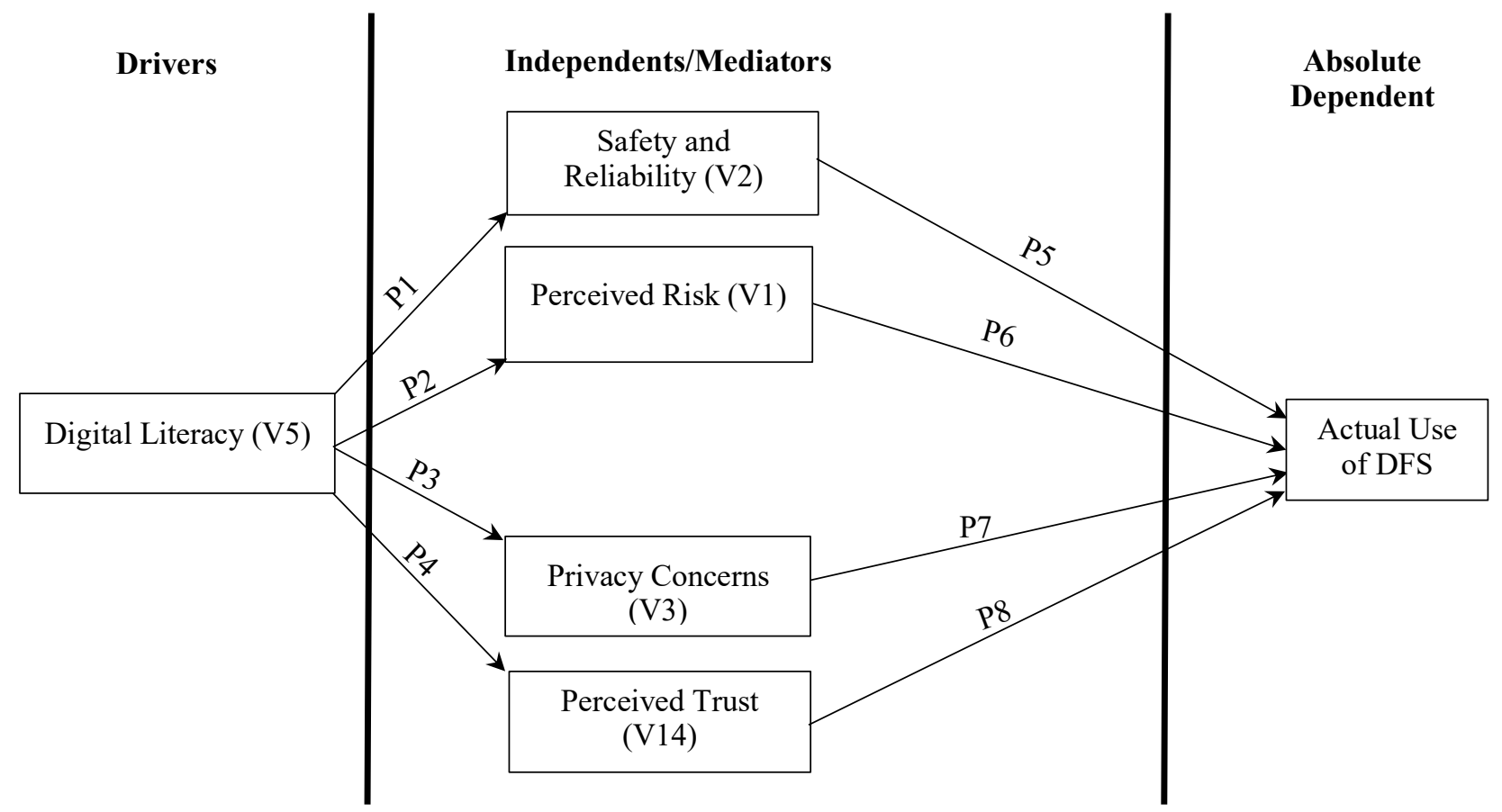

Figure 4. Proposed model for the use of DFS

Out of a number of factors used in the proposed ISM based framework and from our discussion, we have selected some of the prominent variables such as safety and reliability issues, perceived risk, privacy concerns and perceived trust and actual use of DFS for developing the proposed theoretical model (see Figure 4). The proposed model can be empirically validated. We have selected these variables because they have been used very frequently across various models of digital services adoption in the existing literature. Some of these variables are drawn 
from widely known models of information technology/systems adoption include technology acceptance model (Davies et al., 1989), theory of planned behavior (Ajzen, 1991), unified theory of acceptance and use of technology (UTAUT) (Venkatesh et al., 2003), unified model of e-government adoption (UMEGA) (Dwivedi et al., 2017), and extended UTAUT (UTAUT2) (Venkatesh et al., 2012) to name a few.

\subsection{Digital literacy}

Over 3.1 billion people in the world have access to the Internet. However, that leaves around 4.2 billion people outside of digital revolution. Among other factors, individuals need affordable services at reasonable cost when they use digital services. As half of the world's unconnected population (2.2 of the 4.3 billion) dwell in countries like China and India, addressing cost barriers can reduce their digital divide (West, 2015). Research has also found that education is a strong predictor of use of digital activities such as searching for financial information and banking online by an individual (Howard et al., 2001; Hargittai and Hinnant, 2008). Research on digital divide has shown that the access to and use of Internet is heavily impacted by education (van Deursen and van Dijk, 2011).

Liao et al. (2011) examined how privacy, trust and risk perceptions impact customers' beliefs during transactions. In the context of adoption of mobile banking, the same findings are supported by Priya et al. (2018) in their empirical study of Indian customers. The most important issue for digital service providers is to make sure that online transactions are safe, secure and reliable. Safety and reliability standards allow users to make informed decisions about technology-enabled financial services (Grandolini, 2015). The diverse evidence from users suggests that providers should take action to improve safety and reliability of DFS products (McKee et al., 2015). Digital literacy can make all these possible (Gui and Argentin, 2011; Meyers et al., 2013; Nui Polatoglu and Ekin, 2001; Gui and Argentin, 2011; Rodríguezde-Dios et al., 2018). Through digital literacy, service providers can help increase knowledge and ability of customers to manage privacy online, thus enhancing customers personal online safety. Therefore we propose:

Proposition 1. Digital literacy will be positively related to consumer's safety and reliability.

Digital literacy can help the customers in enhancing their online ability and help them to avoid perceived risk (Rodríguez-de-Dios et al., 2018). Zhang et al. (2018) conducted an empirical study and examined how e-health literacy helps to reduce risk in the use of mobile healthcare applications. In the same year, Buehler and Maas (2018) studied that digital literacy plays a significant role in consumer empowerment, which helps them to manage perceived risk. Drawing from the previous literature, we propose the following in the context of DFS:

Proposition 2. Digital literacy will be negatively related to consumer's perceived risk. 
Previous research studies argue that customers are very much concerned about their privacy during online transactions (Liao et al., 2011; Meyers et al., 2013; Priya et al., 2018). But, proper understanding of digital technologies will help customers not only address their privacy concerns but also help them to take advantages of the broad range of available digital financial services that can help in the alleviation of such concerns (Ktoridou et al. 2012). Thus, digital literacy plays a vital role in understanding digital technologies well and mitigation of the privacy concerns of customers (Meyers et al., 2013). Regarding digital skills, it is suggested that more digitally skilled customers are well aware about their privacy concerns (Ktoridou et al., 2012; Lewis, 2018). Therefore, the study proposes the following proposition:

Proposition 3. Digital literacy will be negatively related to consumer's privacy concerns.

While doing any online financial transaction, trust plays a significant role in customers' feelings about security, risk or uncertainties (McKnight et al. 2002; Liao et al., 2011; Ktoridou et al., 2012). If the customers gain trust, they feel secure (McKnight et al. 2002; Priya et al., 2018). A digitally skilled customer can understand and use financial digital services resulting in decrease in ambiguity and uncertainty and can make appropriate use of benefits provided by the service providers resulting in improved trust. Digitally literate customers who are more aware of various issues are more likely to trust and use digital services (Reddick and Anthopoulos, 2014). Therefore we propose:

Proposition 4. Digital literacy will be positively related to customer's perceived trust.

\subsection{Safety and reliability}

Given that DFS is considered riskier than non-financial digital services, the importance of securing user confidence lies in service's safety and reliability (Kim et al., 2009). Users may fear for their security in absence of adequate safety and reliability provided by digital financial services (Grossman, 2017). Walker and Johnson (2006) argued that safety and reliability of technology-enabled financial services are the reasons why people use or choose not to use such services. Safety and reliability enhance organisation's reputation, which in turn plays a vital role in shaping up their initial confidence and assists to maintain their confidence in the future transactions (Kim and Prabhakar, 2004). As a result, we assert that safety and reliability for DFS are key reasons for its use. Therefore, we propose:

Proposition 5. Safety and reliability of DFS will be related to customer's actual use of DFS.

\subsection{Perceived risk}

Since 1960 s, the theory of perceived risk has been used to explain consumer behavior. It represents consumer uncertainty about loss or gain in a specific transaction (Forsythe and Shi, 2003). A number of research models on information systems/technology and digital financial services adoption have discussed the negative and significant influence of perceived risk on 
the adoption intention and actual use of such services (Kesharwani and Bisht, 2012; Dwivedi et al., 2017; Kim et al., 2008). For example, analysing the adoption of transactional egovernment services in India, Dwivedi et al. (2017) found perceived risk as a negative and significant predictor of citizens' intention to use a specific e-government system. Similarly, devising a trust-based consumer decision making model in e-commerce, Kim et al. (2008) found that a consumer's perceived risk reduces their intentions to purchase online. Analysing the Internet banking adoption in India, Kesharwani and Bisht (2012) revealed that perceived risk had a negative impact on behavioral intention of Internet banking adoption. Analysing the online banking usage in Spain, Aldas-Manzano et al. (2009) found that perceived risk had a negative and significant influence on Internet banking usage. Based on prior research, we also propose that perceived risk of using the digital financial services will reduce consumers' usage behavior of such services. Therefore,:

Proposition 6. Perceived risk will be negatively related to consumer's actual use of DFS.

\subsection{Privacy concerns}

Privacy concerns are often considered as one of the key reasons why consumers do not make online purchases over the Internet (George, 2004). While technology has made it easier for organisations to tackle personal data, anxieties about data privacy are increasingly mounting. Financial services providers considering to take advantage of data innovations may find steering appropriate consumer safety and data use as a complicated proposition (Kuhlcke, 2017). As the amount of products and services offered through Internet grows rapidly, consumers are increasingly concerned about their security and privacy issues. Generally speaking, majority of customers would be reluctant to provide their private information (such as credit card related information) over the telephone or Internet (Pikkarainen et al., 2004). Recent research has also revealed that consumers' concerns over the security and privacy protection of an e-commerce system have a significant effect on acceptance of their online shopping and banking (Luarn and Lin, 2005). Realising above discussion, we can infer the following:

Proposition 7. Privacy concerns will be negatively related to consumer's actual use of DFS.

\subsection{Perceived trust}

Perceived trust is a key to consumer's personal and business interactions. Trust is a competitive advantage for DFS too (Ser and Carraro, 2017). Empirical research has shown that trust on online vendors enhances consumer's intention to use their websites (Mukherjee and Nath, 2007). In the online environment, trust is supposed to rule out behaviors such as misuse of personal information and deliberately providing misleading information. It is essential in electronic commerce as the lack of guarantee that a digital service provider will desist from 
undesirable behaviors exposes customers to extensive insecurity. Trust is a key mechanism for reducing customers' uncertainty and hence influence their decisions to trade in digital environment (Suh and Han, 2003). We also believe that consumer's perceived trust of DFS can lead them to positively use such services. Trust becomes more important when we emphasise the underprivileged population that make DFS an obvious choice. Therefore, the following proposition is formulated:

Proposition 8. Perceived trust will be positively related to consumer's actual use of DFS.

\section{Conclusion, Limitations and Future Research}

DFS are a slowing growing mechanism of financial services due to the inherent challenges in the country like India. The objectives of this paper were to recognise those challenges, identify their contextual relationships and develop an ISM model to allow researchers and policymakers promote DFS in India. Eighteen key challenges were considered using a comprehensive literature review. A group of experts were asked to validate the key challenges. We used the contextual relationships between the selected key challenges and implemented ISM to develop their hierarchy for DFS. One hundred fifty-three contextual relationships among major challenges were evaluated using experts' opinions.

Further, ISM methodology helped us to develop a hierarchical ISM model. The challenges such as "risk of using digital services (V1)" and "lack of trust (V14)" were found as top-level variables whereas "high cost and low return related problem (V11)" was evaluated as an independent bottom level variable. The ISM model thus formed would allow the regulatory bodies, practitioners and policymakers toward prioritising their efforts and resources to rectify or eliminate challenges for DFS in India. Fuzzy MICMAC approach was adopted to apprehend challenges with regard to their dependence and driving power.

Like any other research, this study has limitations, which could be considered by researchers as part of the future research in this area. The study has attempted to institute contextual relationships between challenges using ISM methodology, however the model is developed based on literature review and experts' opinions and hence it could expose to bias. Also, this model is not validated using primary survey data. Future research can use structural equation modelling (SEM) as a technique to empirically validate the relevant variables of the proposed framework. Also, ISM methodology may be further extended to TISM (Total Interpretive Structural Modelling) to evaluate key challenges with reference to performance outcomes in future research. The recognised challenges may be evaluated by making use of DEMATEL technique to understand casual relationships. In future, the solutions for optimising or 
eradicating challenges to DFS in Indian context may be analysed with some other MCDM techniques such as AHP, ANP, and TOPSIS etc. to rank the recognised challenges.

\section{References}

Aaluri, S., Narayana, M. S. and Kumar, P. V. (2016), “A study on financial inclusion initiatives and progress with reference to Indian banking industry in digital era", International Journal of Research in Finance and Marketing, Vol. 6 No 10, pp. 125-134.

Adam, A. M., Boadu, M. O. and Frimpong, S. (2018), "Does gender disparity in financial literacy still persist after retirement? Evidence from Ghana", International Journal of Social Economics, Vol. 45 No 1, pp. 18-28.

AFI Global (2016), Afi digital financial services basic terminology. Kuala Lumpur, Malaysia, 2016.

AFI Global (2017), Digital financial services. Accessed from: http://www.afiglobal.org/policy-areas/digital-financial-services on 25th July 2017.

Agi, M. A. and Nishant, R. (2017), "Understanding influential factors on implementing green supply chain management practices: An interpretive structural modelling analysis", Journal of Environmental Management, Vol. 188, pp. 351-363.

Ahluwalia, H.S. and Bhatti, K. K. (2017), "Financial inclusion: Unshackle the impediments to growth", International Journal of Innovative Research and Development, Vol. 6 No. 1, pp. 82-87.

Al-Muftah, H., Weerakkody, V., Rana, N. P., Sivarajah, U., \& Irani, Z. (2018), "Factors influencing e-diplomacy implementation: Exploring causal relationships using interpretive structural modelling”, Government Information Quarterly, Vol. 35, No. 3, pp. 502-514.

Alam, K. and Imran, S. (2015), "The digital divide and social inclusion among refugee migrants: A case in regional Australia”, Information Technology \& People, Vol. 28 No. 2, pp. 344-365.

Aldas-Manzano, J., Lassala-Navarre, C., Ruiz-Mafe, C., and Sanz-Blas, S. (2009), "The role of consumer innovativeness and perceived risk in online banking usage", International Journal of Bank Marketing, Vol. 27 No. 1, pp. 53-75.

Amarante Consulting Group. (2014). "Market study of digital financial services in India", $A$ Summary Report by Amarante Consulting Group, Accessed from: http://amarante consulting.com/upload/publication/Summary\%20DFS\%20Report\%20India\%20June\%22 014_1.pdf on July 27, 2017 on $12^{\text {th }}$ August 2018.

Angelow, W., Omondi, W. and Wanyoike, B. (2016), "Understanding customer inactivity with customer data from Kenya", CGAP: Advancing Financial Inclusion to Improve the Lives 
of the Poor, Accessed from: http://www.cgap.org/blog/understanding-customer-inactivitycustomer-data-kenya on 27th July 2017.

Ashraf, M., Grunfeld, H., Hoque, M. R. and Alam, K. (2017), “An extended conceptual framework to understand information and communication technology-enabled socioeconomic development at community level in Bangladesh", Information Technology \& People, Vol. 30 No 4, pp. 736-752.

Asongu, S. (2015), "The impact of mobile phone penetration on African inequality", International Journal of Social Economics, Vol. 42 No 8, pp. 706-716.

Asongu, S. and Nwachukwu, J. C. (2018), "Comparative human development thresholds for absolute and relative pro-poor mobile banking in developing countries", Information Technology \& People, Vol. 31 No 1, pp. 63-83.

Athey, S., Catalini, C. and Tucker, C. (2017), The Digital Privacy Paradox: Small Money, Small Costs, Small Talk (No. w23488), National Bureau of Economic Research, USA.

Au, Y. A. and Kauffman, R. J. (2008), “The economics of mobile payments: Understanding stakeholder issues for an emerging financial technology application", Electronic Commerce Research and Applications, Vol. 7 No 2, pp. 141-164.

Baker, E. W., Al-Gahtani, S. S. and Hubona, G. S. (2007), "The effects of gender and age on new technology implementation in a developing country: Testing the theory of planned behavior (TPB)", Information Technology \& People, Vol. 20 No. 4, pp. 352-375.

Bourreau, M. and Valletti, T. (2015), "Enabling digital financial inclusion through improvements in competition and interoperability: What works and what doesn't", CGD Policy Paper, Vol. 65, pp. 1-30.

Briggs, C. (2016), “The future of banking for the poor: Lessons from India”, Stanford Social Innovation Review, Accessed from: https://ssir.org/articles/entry/the future of banking for_the_poor_lessons_from_india on 26th July 2017.

Buckley, R. P. (2015), “Consumer protection issues for digital financial services”, Experts Group on Financial Inclusion Policy (EGFIP) Meeting \& Consumer Protection Regulatory Training Tonga, Accessed from: https:/www.clmr.unsw.edu.au/sites/ default/files/attached files/consumer_protection_issues_for_digital_financial_services_n ov_18_2015_-_tonga_training_read-only.pdf, on $5^{\text {th }}$ December 2017.

Buckley, R. P. and Malady, L. (2015), "Building consumer demand for digital financial services-The new regulatory frontier", Journal of Financial Perspectives, Vol. 3 No. 3, pp. 122-137.

Buckley, R. P. and Mas, I. (2016), "The coming of age of digital payments as a field of expertise", Journal of Law, Technology \& Policy, Vol. 71, pp. 71-87. 
Buehler, P., and Maas, P. (2018), "Consumer empowerment in insurance: Effects on performance risk perceptions in decision making", International Journal of Bank Marketing, https://www.emeraldinsight.com/doi/abs/10.1108/IJBM-12-2016-0182

Castle, S., Pervaiz, F. and Yu, S. (2016). "A review of the computer science literature relating to digital financial services", A Report by Digital Financial Services Research Group University of Washington, USA, Accessed from: http://dfs.cs.washington.edu/ docs/Literature_Survey_Research_Brief_Aug2016.pdf on 12 ${ }^{\text {th }}$ October 2018.

Chandrasekhar, C. P. and Ghosh, J. (2018), "The financialization of finance? Demonetization and the dubious push to cashlessness in India", Development and Change, Vol. 49 No. 2, pp. 420-436.

Chauhan, S. (2015), “Acceptance of mobile money by poor citizens of India: Integrating trust into the technology acceptance model”, Info, Vol. 17 No. 3, pp. 58-68.

Collis, J., \& Hussey, R. (2014). Business research: A practical guide for undergraduate and postgraduate students. Palgrave Macmillan, New York.

Dara, N.R. (2018), “The global digital financial services: A critical review to achieve for digital economy in emerging markets", International Research Journal of Human Resources and Social Sciences, Vol. 5 No. 1, pp. 141-163.

Das, P., Verburg, R., Verbraeck, A. and Bonebakker, L. (2018), "Barriers to innovation within large financial services firms: An in-depth study into disruptive and radical innovation projects at a bank", European Journal of Innovation Management, Vol. 21 No. 1, pp. 96112.

David-West, O., Iheanachor, N. and Kelikume, I. (2018), “A resource-based view of Digital Financial Services (DFS): An exploratory study of Nigerian providers", Journal of Business Research, Vol. 88, pp. 513-526.

Deichmann, U., Goyal, A. and Mishra, D. (2016), "Will digital technologies transform agriculture in developing countries?", Agricultural Economics, Vol. 47 No. S1, pp. 21-33.

Dubey, R. and Ali, S. S. (2014), "Identification of flexible manufacturing system dimensions and their interrelationship using total interpretive structural modeling and fuzzy MICMAC analysis", Global Journal of Flexible Systems Management, Vol. 15 No. 2, pp. 131-143.

Dwivedi, Y. K., Rana, N. P., Janssen, M., Lal, B., Williams, M. D., and Clement, M. (2017), "An empirical validation of a unified model of electronic government adoption (UMEGA)", Government Information Quarterly, Vol. 34, No. 2, pp. 211-230.

Dwivedi, Y. K., Janssen, M., Slade, E., Rana, N. P., Weerakkody, V., Millard, J., Hidders, A. J. H., and Snijder, D. (2017), "Driving Innovation through Big Open Linked Data (BOLD): 
Exploring Antecedents using Interpretive Structural Modelling”, Information Systems Frontiers, Vol. 19 No. 2, pp. 197-212.

Dwivedi, Y. K., Sahu, G. P., Rana, N. P., Singh, M. and Chandwani, R. K. (2016), "Common

Services Centres (CSCs) as an approach to bridge the digital divide: Reflecting on challenges and obstacles", Transforming Government: People, Process and Policy, Vol. 10 No. 4, pp. 511-525.

Fatima, A. (2011), "E-banking security issues-Is there a solution in biometrics?", Journal of Internet Banking and Commerce, Vol. 16 No. 2, pp. 1-9.

FII. (2014). The 2014 Intermedia Financial Inclusion Insight (FII) Survey Report, Accessed from: http://finclusion.org/wp-content/uploads/2014/05/India-Country-ComparisonsRep ort.pdf on 14 October 2018.

Finau, G., Rika, N., Samuwai, J. and McGoon, J. (2016). "Perceptions of digital financial services in rural Fiji”, Information Technologies \& International Development, Vol. 12 No. 4, pp. 11-21.

Fitzgerald, M., Kruschwitz, N., Bonnet, D. and Welch, M. (2014), "Embracing digital technology: A new strategic imperative”, MIT Sloan Management Review, Vol. 55 No. 2, pp. 1-12.

Forsythe, S. M., and Shi, B. (2003), "Consumer patronage and risk perceptions in Internet shopping”, Journal of Business Research, Vol. 56, No. 11, pp. 867-875.

Foster, J. (2016). "TPP and the future of the digital economy in the Asia pacific region", In Proceedings of IEEE International Conference on Advanced Computer Science and Information Systems, pp. 1-8.

Gabor, D. and Brooks, S. (2017), "The digital revolution in financial inclusion: international development in the fintech era", New Political Economy, Vol. 22 No. 4, pp. 423-436.

Gates Foundation (2017), "Digital payments can benefit the poor and be good for business", $A$ Report by Gates Foundation, Accessed from: https://www.gatesfoundation.org/MediaCenter/Press-Releases/2013/09/Digital-Payments-Can-Benefit-the-Poor on 25th July $\underline{2017}$.

George, J. F. (2004), “The theory of planned behavior and Internet purchasing”, Internet Research, Vol. 14 No. 3, pp. 198-212.

Gomber, P., Kauffman, R. J., Parker, C. and Weber, B. W. (2018), "On the Fintech revolution: Interpreting the forces of innovation, disruption, and transformation in financial services. Journal of Management Information Systems, Vol. 35 No. 1, pp. 220-265. 
Gorane, S. J. and Kant, R. (2013), "Supply chain management: Modeling the enablers using ISM and fuzzy MICMAC approach”, International Journal of Logistics Systems and Management, Vol. 16 No. 2, pp. 147-166.

Grandolini, G. M. (2015), "Five challenges prevent financial access for people in developing countries", The World Bank, Accessed from http://blogs.worldbank.org/voices/fivechallenges-prevent-financial-access-people-developing-countries on 17th March 2017.

Grossman, J. (2017), "Executive summary of ITU focus group digital financial services outputs", Focus Group Technical Report, Accessed from https://www.itu.int/en/ITUT/focusgroups/dfs/Documents/201703/ITU_FGDFS_Executive-summary.pdf, 17th March 2019.

Gui, M., and Argentin, G. (2011), "Digital skills of internet natives: Different forms of digital literacy in a random sample of northern Italian high school students", New Media and Society, Vol. 13 No. 6, pp. 963-980.

Gupta, D. K. (2017), “Demonetization in India 2016--Mother Tongue Friendly E-Delivery Banking Channels for Cashless Growth", Accessed from: https://papers.ssrn.com /sol3/papers.cfm? abstract_id=2894129 on $19^{\text {th }}$ April 2018.

Gupta, S., Yun, H., Xu, H. and Kim, H. W. 2(017), “An exploratory study on mobile Banking adoption in Indian metropolitan and urban areas: A scenario-based experiment", Information Technology for Development, Vol. 23 No. 1, pp. 127-152.

Haider, H. (2018). "Innovative financial technologies to support livelihoods and economic outcomes", K4D Helpdesk Report. Institute of Development Studies, Brighton, UK.

Hargittai, E., and Hinnant, A. (2008). 'Digital inequality: Differences in young adults' use of the Internet", Communication Research, Vol. 35 No. 5, pp. 602-621.

Harsh, S. and Wright, G. (2016), "Real and Perceived Risk in Indian Digital Financial Services", Accessed from: http://blog.microsave.net/real-and-perceived-risk-in-indian digital-financial-services on August 16, 2017.

Holley, E. (2015), "Banks scramble to keep up with digital race for pace”, Accessed from: http://www.bankingtech.com/287492/banks-scramble-to-keep-up-with-digital-race-for pace.

Howard, P. N., Rainie, L., \& Jones, S. (2001), "Days and nights on the Internet: The impact of a diffusing technology", American Behavioral Scientist, Vol. 45 No. 3, pp. 383-404.

Hughes, D. L., Dwivedi, Y. K., Rana, N. P., and Simintiras, A. C. (2016), "Information Systems Project Failure - Analysis of Causal Links using Interpretive Structural Modelling”, Production Planning \& Control, Vol. 27 No. 16, 1313-1333. 
IAMAI (2018), "Only 16\% of rural users access Internet for digital payments", A Report by Internet and Mobile Association of India (IAMAI), Accessed from: https://www. livemint.com/Politics/PhY0kTxoJqq6U9GISIpSaK/Only-16-of-rural-users-accessInternet-for-digital-payments.html on $5^{\text {th }}$ November 2018.

Janssen, M., Rana, N. P., Slade, E., and Dwivedi, Y. K. (2018), "Trustworthiness of Digital Government Services: Deriving a comprehensive theory through Interpretive Structural Modelling”, Public Management Review, Vol. 20 No. 5, pp. 647-671.

Kanobe, F., Alexander, P. M. and Bwalya, K. J. (2017), "Policies, regulations and procedures and their effects on mobile money systems in Uganda", The Electronic Journal of Information Systems in Developing Countries, Vol. 83 No. 1, pp. 1-15.

Karlan, D., Kendall, J., Mann, R., Pande, R., Suri, T. and Zinman, J. (2016), Research and impacts of digital financial services (No. 22633), National Bureau of Economic Research, USA.

Kemp, R. (2013), "Mobile payments: Current and emerging regulatory and contracting issues", Computer Law \& Security Review, Vol. 29 No. 2, pp. 175-179.

Kendall, J., Maurer, B., Machoka, P. and Veniard, C. (2011), “An emerging platform: From money transfer system to mobile money ecosystem", Innovations: Technology, Governance, Globalization, Vol. 6 No. 4, pp. 49-64.

Kesharwani, A., and Bisht, S. S. (2012), “The impact of trust and perceived risk on internet banking adoption in India: An extension of technology acceptance model", International Journal of Bank Marketing, Vol. 30 No. 4, pp. 303-322.

Khan, U. and Haleem, A. (2015). "Improving to smart organization: An integrated ISM and fuzzy-MICMAC modeling of barriers", Journal of Manufacturing Technology Management, Vol. 26 No. 6, pp. 807-829.

Khokhar, A. S. (2016), “Digital literacy: How prepared is India to embrace it?", International Journal of Digital Literacy and Digital Competence, Vol. 7 No. 3, pp. 1-12.

Kim, D. J., Ferrin, D. L., and Rao, H. R. (2008), “A trust-based consumer decision-making model in electronic commerce: The role of trust, perceived risk, and their antecedents," Decision Support Systems, Vol. 44 No. 2, pp. 544-564.

Kim, G., Shin, B., \& Lee, H. G. (2009), "Understanding dynamics between initial trust and usage intentions of mobile banking", Information Systems Journal, Vol. 19 No. 3, pp. 283 311.

Kim, K. K. and Prabhakar, B. (2004), "Initial trust and the adoption of B2C e-Commerce: the case of internet banking", ACM SIGMIS Database, Vol. 35, pp. 50-64. 
Ktoridou, D., Eteokleous, N., and Zahariadou, A. (2012), “Exploring parents' and children's awareness on internet threats in relation to internet safety", Campus-Wide Information Systems, Vol. 29 No. 3, pp. 133-143.

Kuhlcke, K. (2017), "Digital financial services, data sharing and related privacy concerns", Insight2Impact, Accessed from http://i2ifacility.org/insights/articles/digital-financialservices-data-sharing-and-related-privacy-concerns?entity=news on 14 ${ }^{\text {th }}$ January 2019.

Kumar, D. and Goyal, N. (2016), "Security Issues in M-Commerce for online transaction”, In Proceedings of 2016 IEEE 5th International Conference on Reliability Infocom Technologies and Optimization (Trends and Future Directions), pp. 409-414.

Kumar, K. (2015), "2015 set to be big year for digital financial inclusion in India”, Accessed from: http://www.cgap.org/blog/2015-set-be-big-year-digital-financial-inclusion-india, CGAP on 26th July 2017.

Kumar, S., Luthra, S., Govindan, K., Kumar, N., and Haleem, A. (2016), "Barriers in green lean six sigma product development process: An ISM approach”, Production Planning \& Control, Vol. 27 No. 7-8, pp. 604-620.

Lauer, K. and Lyman, T. (2015), "Digital financial inclusion", online available at: http://www.cgap.org/ publications/digital-financial-inclusion on 26th July 2017.

Leeflang, P. S., Verhoef, P. C., Dahlström, P. and Freundt, T. (2014), “Challenges and solutions for marketing in a digital era", European Management Journal, Vol. 32 No. 1, pp. 1-12.

Lewis, D. (2018), “Computers May Not Make Mistakes but Many Consumers Do", In International Conference on HCI in Business, Government, and Organizations (pp. 361371), Springer, Cham.

Liao, C., Liu, C. C., and Chen, K. (2011), "Examining the impact of privacy, trust and risk perceptions beyond monetary transactions: An integrated model”, Electronic Commerce Research and Applications,

Lifen Zhao, A., Koenig-Lewis, N., Hanmer-Lloyd, S. and Ward, P. (2010), “Adoption of internet banking services in China: is it all about trust?", International Journal of Bank Marketing, Vol. 28 No. 1, pp. 7-26.

Lloyd, A. D., Antonioletti, M. and Sloan, T. M. (2016), “Able but not willing? Exploring divides in digital versus physical payment use in China", Information Technology \& People, Vol. 29 No. 2, pp. 250-279.

Luarn, P., and Lin, H. H. (2005), "Toward an understanding of the behavioral intention to use mobile banking", Computers in Human Behavior, Vol. 21 No. 6, pp. 873-891. 
Luthra, S. and Mangla, S. K. (2018), "When strategies matter: Adoption of sustainable supply chain management practices in an emerging economy's context", Resources, Conservation and Recycling, Vol. 138, pp. 194-206.

Luthra, S., Kumar, S., Kharb, R., Ansari, M. F. and Shimmi, S. L. (2014), “Adoption of smart grid technologies: An analysis of interactions among barriers", Renewable and Sustainable Energy Reviews, Vol. 33, pp. 554-565.

Mangla, S. K, Luthra, S., Mishra, N., Singh, A., Rana, N. P., Dora, M., and Dwivedi, Y. K. (2017), "Barriers to effective circular supply chain management in a developing country context", Production Planning \& Control, Vol. 29 No. 6, pp. 551-569.

Manyika, J., Lund, S., Singer, M., White, O. and Berry, C. (2016). Digital Finance for All: Powering Inclusive Growth in Emerging Economies (Rep.). New York, NY: McKinsey Global Institute, McKinsey \& Company.

Mattern, M. and McKay, C. (2018), "Building inclusive payment ecosystems in Tanzania and Ghana", CGAP Focus Note; No. 110, World Bank, Washington, DC., Accessed from: https://openknowledge.worldbank.org/handle/10986/30274 on 30th October 2018.

Mazer, R. and Rowan, P. (2016), "Competition in mobile financial services: Lessons from Kenya and Tanzania1", The African Journal of Information and Communication, Vol. 17, pp. 39-59.

McKee, K., Kafenberger, M., and Zimmerman, J. M. (2015), "Doing digital finance right: The case of stronger mitigation of customer risks", Focus Note-CGAP, Accessed from https://www.cgap.org/sites/default/files/researches/documents/Focus-Note-Doing-DigitalFinance-Right-Jun-2015.pdf on 17th March 2019, pp. 1-37.

McKnight, D. H., Choudhury, V., and Kacmar, C. (2002). The impact of initial consumer trust on intentions to transact with a web site: a trust building model. The Journal of Strategic Information Systems, Vol. 11 No. 3-4, pp. 297-323.

Measuring the Information Society Report (2017). ITU Measuring the Information Society Report, Accessed from: https://www.itu.int/en/ITUD/Statistics/Pages/publications/ mis2017.aspx on 30th October 2018.

Meyers, E. M., Erickson, I., and Small, R. V. (2013), "Digital literacy and informal learning environments: an introduction", Learning, Media and Technology, Vol. 38 No. 4, pp. 355367.

MicroSave (2016). Customer vulnerability, trust and risk in Indian digital financial services. MicroSave's Study for the Omidyar Network. Accessed from: http://blog.microsave.net/ customer-vulnerability-trust-and-risk-in-indian-digital-financial-services/ on 8th November 2018. 
Mishra, N., Singh, A., Rana, N. P., and Dwivedi, Y. K. (2017), "Interpretive Structural Modelling and Fuzzy MICMAC Approaches for Customer Centric Beef Supply Chain: Application of a Big Data Technique”, Production Planning \& Control, Vol. 28 No. 11-12, pp. 945-963.

Mukherjee, A. and Nath, P. (2007), "Role of electronic trust in online retailing: A reexamination of the commitment-trust theory", European Journal of Marketing, Vol. 41 Nos 9/10, pp. 1173-1202.

Nedungadi, P. P., Menon, R., Gutjahr, G., Erickson, L. and Raman, R. (2018), “Towards an inclusive digital literacy framework for digital India", Education+ Training, Vol. 60 No. 6, pp. 516-528.

Nesse, P. J., Risnes, O. and Hallingby, H. S. (2018), "Management of mobile financial services-Review and way forward", In Finance \& Economics Readings (pp. 49-67). Springer, Singapore.

Nui Polatoglu, V., and Ekin, S. (2001), “An empirical investigation of the Turkish consumers' acceptance of Internet banking services", International Journal of Bank Marketing, Vol. 19 No. 4, pp. 156-165.

Patil, P. P., Dwivedi, Y. K. and Rana, N. P. (2017), "Digital payments adoption: An analysis of literature", In Conference on e-Business, e-Services and e-Society (pp. 61-70). Springer, Cham.

Pikkarainen, T., Pikkarainen, K., Karjaluoto, H., and Pahnila, S. (2004), “Consumer acceptance of online banking: An extension of the technology acceptance model", Internet Research, Vol. 14 No. 3, pp. 224-235.

Priya, R., Gandhi, A. V., and Shaikh, A. (2018), "Mobile banking adoption in an emerging economy: An empirical analysis of young Indian consumers", Benchmarking: An International Journal, Vol. 25 No. 2, pp. 743-762.

Rana, N., Luthra, S. and Rao, H. R. (2018), "Developing a framework using interpretive structural modeling for the challenges of digital financial services in India", In the Proceedings of Twenty-Second Pacific Asia Conference on Information Systems (PACIS), Vol. 53, Accessed from: https://aisel.aisnet.org/cgi/viewcontent.cgi?article=1052

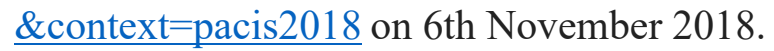

Rana, N. P., Barnard, D., Baabdullah, A., Rees, D. and Roderisk, S. (2019), “Exploring Barriers of M-Commerce Adoption in SMEs in the UK: Developing a Framework using ISM", International Journal of Information Management, Vol. 44, pp. 141-153.

Rani, S. (2016). "Digital India: Unleashing prosperity", Indian Journal of Applied Research, Vol. 6 No. 4, pp. 238-243. 
Reddick, C., \& Anthopoulos, L. (2014), "Interactions with e-government, new digital media and traditional channel choices: citizen-initiated factors", Transforming Government: People, Process and Policy, Vol. 8 No. 3, pp. 398-419.

Rodríguez-de-Dios, I., van Oosten, J. M., and Igartua, J. J. (2018), “A study of the relationship between parental mediation and adolescents' digital skills, online risks and online opportunities", Computers in Human Behavior, Vol. 82 No. 1, pp. 186-198.

Santosham, S. (2015), "Closing the gender gap in mobile phone access and use", Better than Cash Alliance, Accessed from: https://www.betterthancash.org/news/blogsstories/closingthe-gender-gap-in-mobile-phone-access-and-use on 28th July 2017.

Scott, S. V., Van Reenen, J. and Zachariadis, M. (2017), "The long-term effect of digital innovation on bank performance: An empirical study of SWIFT adoption in financial services", Research Policy, Vol. 46 No. 5, pp. 984-1004.

Ser, J. D. and Carraro, M. (2017), "In Digital Financial Services We Trust”, BFA, Accessed from https://medium.com/f4life/in-digital-financial-services-we-trust-850352dea2e9 on $14^{\text {th }}$ January 2019.

Setia, P., Venkatesh, V. and Joglekar, S. (2013), "Leveraging digital technologies: How information quality leads to localized capabilities and customer service performance", $M I S$ Quarterly, Vol. 37 No. 2, pp. 565-590.

Shah, P. and Dubhashi, M. (2015), "Review paper on financial inclusion-The means of inclusive growth", Chanakya International Journal of Business Research, Vol. 1 No. 1, pp. $37-48$.

Shareef, M. A., Dwivedi, Y. K., Kumar, V., Davies, G., Rana, N. and Baabdullah, A. (2018), "Purchase intention in an electronic commerce environment: A trade-off between controlling measures and operational performance", Information Technology \& People, https://doi.org/10.1108/ITP-05-2018-0241.

Sharma, S. K., Mangla, S. K., Luthra, S. and Al-Salti, Z. (2018), "Mobile wallet inhibitors: Developing a comprehensive theory using an integrated model", Journal of Retailing and Consumer Services, Vol. 45, pp. 52-63.

Siddiquee, N. A. (2016), "E-government and transformation of service delivery in developing countries: The Bangladesh experience and lessons", Transforming Government: People, Process and Policy, Vol. 10 No. 3, pp. 368-390.

Sindhu, S., Nehra, V. and Luthra, S. (2016), "Identification and analysis of barriers in implementation of solar energy in Indian rural sector using integrated ISM and fuzzy MICMAC approach”, Renewable and Sustainable Energy Reviews, Vol. 62, pp. 70-88. 
Singhal, H. and Kar, A. K. (2015), "Information security concerns in digital services: Literature review and a multi-stakeholder approach", In Proceedings of IEEE International Conference on Advances in Computing, Communications and Informatics, pp. 901-906.

Sinha, S. (2018), “Gender digital divide in India: Impacting women's participation in the labour market”, In Reflecting on India's Development (pp. 293-310). Springer, Singapore.

Srivastava, A. K. and Sharma, S. (2017), "Social justice through Aadhaar: An e-policy initiative", In Technology, Society and Sustainability, L. W. Zacher (eds.), New York: Springer-Verlag, pp. 83-97.

Suh, B., and Han, I. (2003), "The impact of customer trust and perception of security control on the acceptance of electronic commerce", International Journal of Electronic Commerce, Vol. 7 No. 3, pp. 135-161.

Sundaram, N. and Sriram, M. M. (2016). "Financial inclusion in India: A review", International Journal of Applied Engineering Research, Vol. 11 No. 3, pp. 1575-1578.

Tarhini, A., El-Masri, M., Ali, M. and Serrano, A. (2016), "Extending the UTAUT model to understand the customers' acceptance and use of internet banking in Lebanon: A structural equation modeling approach", Information Technology \& People, Vol. 29 No. 4, pp. 830849.

Thorseng, A. A. and Grisot, M. (2017), "Digitalization as institutional work: A case of designing a tool for changing diabetes care", Information Technology \& People, Vol. 30 No. 1, pp. 227-243.

van Deursen, A., and Van Dijk, J. (2011), "Internet skills and the digital divide", New Media \& Society, Vol. 13 No. 6, pp. 893-911.

Walker, R. H., \& Johnson, L. W. (2006), "Why consumers use and do not use technologyenabled services", Journal of Services Marketing, Vol. 20 No. 2, pp. 125-135.

Warfield, J. N. (1974), "Toward interpretation of complex structural models", IEEE Transactions on Systems, Man, and Cybernetics, Vol. 4 No. 5, pp. 405-417.

Weber, R. H. and Darbellay, A. (2010), "Legal issues in mobile banking”, Journal of Banking Regulation, Vol. 11 No. 2, pp. 129-145.

Weill, P. and Woerner, S. L. (2015), "Thriving in an increasingly digital ecosystem", MIT Sloan Management Review, Vol. 56 No. 4, pp. 27-34.

West, D. M. (2015), "Digital divide: Improving internet access in the developing World through affordable services and diverse content", Center for Technology Innovation at Brookings, Accessed from: https://www.brookings.edu/wp-content/uploads/2016/06/ West_Internet-Access.pdf on $11^{\text {th }}$ January 2019. 
Wright, G. A. N., Chopra, P., Mehta, S. and Shukla, V. (2013), "Financial inclusion through electronic and mobile banking", Business, Economy and Finance, Accessed from: https://www.slideshare.net/MicroSaveConsulting/financial-inclusion-through-embanking on 27th July 2017.

Zhang, X., Yan, X., Cao, X., Sun, Y., Chen, H., and She, J. (2018), “The role of perceived ehealth literacy in users' continuance intention to use mobile healthcare applications: an exploratory empirical study in China", Information Technology for Development, Vol. 24 No. 2, pp. 198-223.

Zhu, X., Song, B., Ni, Y., Ren, Y. and Li, R. (2016), “Digital finance-From traditional finance to digital and internet finance", In Business Trends in the Digital Era, Singapore: SpringerVerlag, pp. 161-190. 